Article

\title{
A Circularity Evaluation of New Feed Categories in The Netherlands-Squaring the Circle: A Review
}

\author{
Daniel Puente-Rodríguez *, Harmen van Laar (D) and Maayke Veraart
}

\begin{abstract}
Wageningen Livestock Research, Wageningen University \& Research, 6708 PB Wageningen, The Netherlands; harmen.vanlaar@wur.nl (H.v.L.); maayke.veraart@wur.nl (M.V.)

* Correspondence: daniel.puenterodriguez@wur.nl or d.puenterodriguez@gmail.com; Tel.: +31-(0)-317-485400
\end{abstract}

check for updates

Citation: Puente-Rodríguez, D.; van Laar, H.; Veraart, M. A Circularity Evaluation of New Feed Categories in The Netherlands-Squaring the Circle: A Review. Sustainability 2022, 14, 2352. https://doi.org/10.3390/ su14042352

Academic Editor: Giuseppe Todde

Received: 30 December 2021

Accepted: 15 February 2022

Published: 18 February 2022

Publisher's Note: MDPI stays neutral with regard to jurisdictional claims in published maps and institutional affiliations.

Copyright: () 2022 by the authors. Licensee MDPI, Basel, Switzerland. This article is an open access article distributed under the terms and conditions of the Creative Commons Attribution (CC BY) license (https:// creativecommons.org/licenses/by/ $4.0 /)$.

\begin{abstract}
The concept of circularity is currently proposed to address key sustainability issues affecting and affected by livestock production. Through a desk study, this paper evaluates some feed sources that are being developed in The Netherlands as an alternative to current feeds, namely food waste; seaweed; and localized production and alternative plant-based feed sources. These feed categories are evaluated according to four circularity criteria. The first two criteria concern standard circularity principles aimed at both stopping and preventing environmental damage as well as a focus on natural resources use efficiency: (1) safeguard the health of ecosystems and (2) avoid the production of unnecessary products and use/recycle biomass effectively, as well as evaluating possible foodfeed competition. In addition, two 'people' and 'animal' centred principles have been integrated: (3) fairness and accessibility and (4) animal health and wellbeing. The article concludes that people and animal centred principles are key to thinking of, developing, implementing, and evaluating circularity initiatives. Moreover, the article suggests that categories such as the local production of soya (approx. $132 \mathrm{ha}$ ) or seaweed (approx. 10-15 ha) are as yet irrelevant regarding production volumes within the Dutch context. However, some feed sources such as seaweed, insects, livestock leftovers produced at farms and abattoirs, and food waste might strengthen the transition towards more circular and sustainable practices.
\end{abstract}

Keywords: circularity; feed; evaluation framework; food waste; seaweed; localized production; livestock; The Netherlands

\section{Introduction}

Livestock is a pivotal element of agro-ecosystems and circularity. In a context in which around 690 million people are still hungry and in which 2 billion people "don't have regular access to safe, nutritious and sufficient food" (www.fao.org/hunger/en/, accessed on 1 April 2021), it contributes to the food security and sovereignty of the world's population. The Food and Agriculture Organization of the United Nations (FAO) reports that livestock provides 34\% of the world's total protein intake (www.fao.org/animal-production/en/, accessed on 1 March 2021). Besides, van Zanten and her colleagues [1] argue that within a circular economy, i.e., without competing for resources and land that can be utilized directly for human consumption, livestock could provide 9-23 g/per capita of our required 50-60 g/per capita daily protein. Recent estimates indicate that this could reach $31 \mathrm{~g} / \mathrm{per}$ capita if low-opportunity-cost feeds, especially grass resources (e.g., as grazed or conserved as silage or hay), are available [2]. Furthermore, livestock contributes to almost $40 \%$ of the agricultural output in the so-called developed countries and $20 \%$ in the developing world (www.fao.org/animal-production/en/, accessed on 1 March 2021). In a prospective analysis for the agricultural (and fish) commodity markets, the Organisation for Economic Co-operation and Development (OECD) and the FAO estimate that, due to, among other reasons, population growth and the ongoing transition towards a higher intake of animal products, global livestock production will grow 14\% before 2029 [3]. 
However, there are also some challenges ahead. A higher consumption of animal products implies a larger usage of agricultural (and fishery) products as feed for the growing livestock herd. This might lead to some tensions between feed and food production. Feed competes with food production for fertile soils. For instance, it is estimated that $40 \%$ of the world's land is used by agriculture, of which $70 \%$ is covered by pastures [3]. Currently, $52 \%$ of the calories produced are for food; feed accounts for about $31 \%$ calories; and " $17 \%$ are used as either biofuel, seed, or raw products in industrial applications" [3]. Moreover, it is estimated that livestock consumes 6 billion tonnes (dry matter) feed "including one third of global cereal production" [4]. Furthermore, 1.7 billion ton of "cereals, protein meals and various processing by-products (e.g., dried distillers grain, cereal bran) are used as feed" and it is estimated that by 2029 it will reach almost 2 billion tons [3]. Mottet et al. [4] claim that "producing $1 \mathrm{~kg}$ of boneless meat requires an average of $2.8 \mathrm{~kg}$ human-edible feed in ruminant systems and $3.2 \mathrm{~kg}$ in monogastric systems". However, note that some of these feed products are made with materials that humans do not currently eat, approx. 86\% [4]. Yet, under the perspective of a circular agriculture and economy, these waste products might acquire a higher status. On the other side, improvements in feed use efficiency and yield production efficiency can address this competition by, for instance, reducing the expansion of agricultural activities to non-agricultural areas [4].

Moreover, the production of feed has negative consequences for biodiversity and climate change by, e.g., deforestation, greenhouse gas emissions (GHG), and nitrogen deposition. It is estimated that livestock production is responsible for around $14.5 \%$ of the human-induced GHG [5]. Reisinger et al. [6] estimated that livestock production contributed "about $19 \%$ of the total modelled warming of $0.81^{\circ} \mathrm{C}$ from all anthropogenic sources in 2010". It is estimated that before 2029 the GHG emissions of agriculture will increase by $6 \%$, livestock will be responsible for $80 \%$ of this increase [3].

The literature claims that the predicted livestock production and consumption increases will mainly occur in the low- or middle-income regions and countries. However, some high-income regions such as Western Europe, and countries such as The Netherlands that have large intensive livestock production sectors, already suffer some negative consequences, for instance, regarding large volumes of manure and a subsequent mineral unbalance $[7,8]$ or/and GHG emissions [6,9]. Researchers, policy makers, and practitioners claim that circularity can address some of these challenges [10-12]. Accordingly, the Dutch government is formulating policies to address tensions emerging with livestock production and to make its agricultural sector a "world leader in circular agriculture" [13,14].

This article presents the results of a desk study conducted to answer the question of how new feed categories and initiatives contribute to the circularity of the Dutch agriculture. These feed categories are evaluated according to a specific set of criteria based on central principles and aspects of circularity: (1) safeguard the health of ecosystems; and (2) avoid the production of unnecessary products and use/recycle biomass effectively, while also regarding possible food-feed competition. Moreover, we propose to include also a social and animal-centred criteria, (3) fairness and accessibility and (4) animal health and wellbeing.

The Netherlands is an advanced economy that has capital-intensive livestock production in which feed is used in animal breeds with high feed conversion efficiency. In this article, Section 2 introduces the Dutch feed practices focusing on production, consumption, stakeholders, and key challenges. Section 3 elaborates a basic framework formed by four assessment criteria. Three relevant feed categories are evaluated in Section 4, namely food waste; seaweed/macroalgae; and localized production and alternative plant-based feed sources. In the last section we summarize the results of the evaluation and reflect on the role played by these new feed practices within the circularity transition.

\section{Methodological Notes}

This article presents the results of a desk study conducted to analyse current feed practices, including sustainability issues and emerging feed categories in The Netherlands. 
Key elaborations of the concept of circularity were reviewed, placing particular attention into its articulation within the agricultural and livestock domains. In this way, a new set of specific criteria was elaborated to evaluate a number of feed categories. The evaluation of feed categories through the proposed circularity criteria was conducted on the basis of the literature, governmental and industry figures (grey literature), and expert consultation regarding livestock leftovers produced at farms and abattoirs and seaweed production.

This study evaluates a limited number of emerging feed categories and concerns just one country. However, it provides insights in the current state of the circularity transition in The Netherlands regarding feed. According to the literature, the feed categories here assessed are key new feed sources. Moreover, the framework here proposed can be applied to conduct similar and more in depth (including, for instance, total protein supply) evaluations of other relevant feed categories (e.g., insects and microalgae) in The Netherlands and beyond.

\section{Dutch Feed Practices}

Since the end of the Second World War, The Netherlands has enlarged and intensified its livestock production (see Figure 1). In 2020, more than 100 million chickens, about 12 million pigs, approx. 4 million cattle, almost 900,000 sheep, 820,000 ducks for slaughter, 590,000 turkeys, 630,000 goats, 336,000 rabbits, and about 90,000 (on agricultural farms, excluding privately owned) horses and ponies were kept (CBS Statline (https: / / opendata.cbs. $\mathrm{nl} /$ \#/CBS/nl/dataset/70072ned/table?searchKeywords=veehouderij\%20aantal\%20dieren, accessed on 1 June 2021)). The livestock population of cattle, pigs, and chickens have stabilized over the last 20 years, and the number of animals increased for other categories, e.g., goats. Moreover, in the same period, the number of farms with cattle, pigs, and chickens dropped by $-47.6 \%,-75.6 \%$, and $-54.9 \%$, respectively, while the number of animals per farm increased.

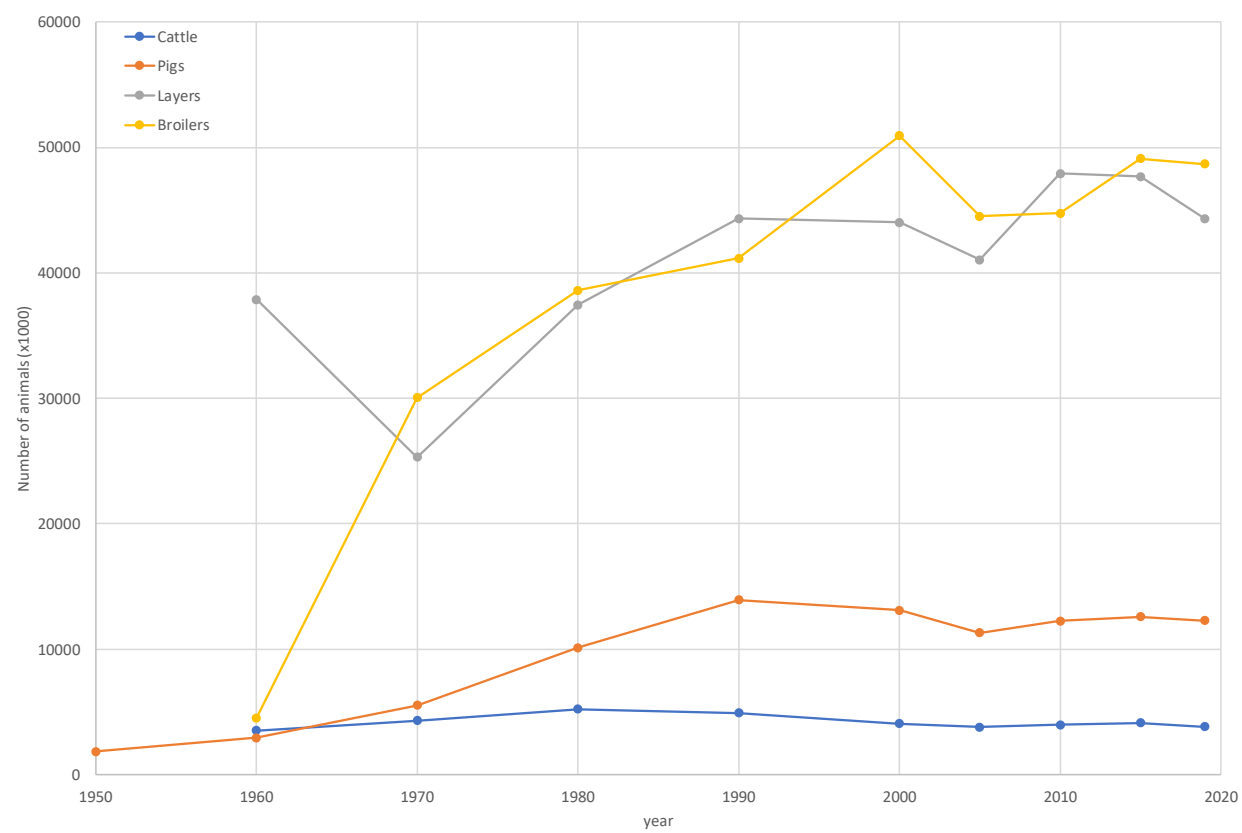

Figure 1. Animals numbers in The Netherlands from 1950-2019; dots indicate a data point-CBS Statline, 2021.

The Netherlands is an export-oriented economy. The Dutch agricultural sector export for 2020 was estimated at 95.6 billion euros with an estimated agricultural product import of 67.1 billion euros. This results in a positive trade balance of 28.5 billion euros [15]. The agricultural product import, export, and trade balance represent $16.0 \%, 20.0 \%$, and $49.7 \%$ of the total Dutch import, export, and trade balance, respectively [15]. These numbers include all agricultural products. Figure 2 gives the export values for agricultural products. Direct 
animal production-related products contribute to around $25 \%$ of total agricultural export. Some livestock related products are not represented in this figure, for instance, the export of living animals, which has an estimated value of 1.9 billion euros [15].

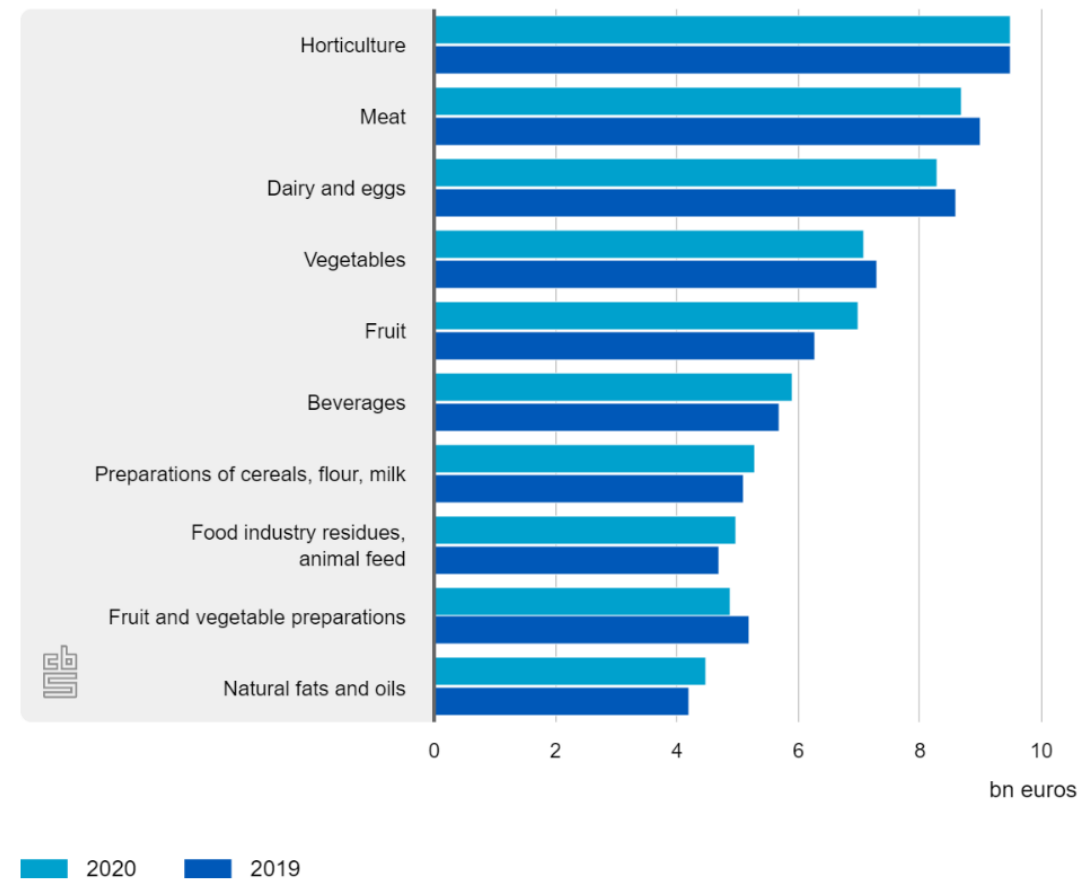

Figure 2. Export value (in bn euros) of agricultural goods, 2019-2020. Based on estimates (https:/ / www.cbs.nl/nl-nl/nieuws/2021/03/landbouwexport-blijft-op-de-been (accessed on 1 January 2021)).

In order to live, and thereby to produce high quality human-edible proteins, livestock has to eat. Depending on the animals kept on farm, farms receive animal feed in different ways. Dairy farms generally produce a large proportion of their feed in the form of grass silage and maize silage grown on the farm. Often, the forage is supplemented with hay or other products bought from forage traders. This is then combined with compound feeds or sometimes individual raw materials that are bought from the compound feed industry directly or from feed traders. Additionally, co-products that become available from the production of human food by the food industry can be used to replace a part of the compound feed. These are purchased either from compound feed industry, feed traders, or co-product traders [16]. Pig and chicken (and other poultry) farms generally obtain the largest part of their feed also from the compound feed industry, directly or through feed traders. These farms may use also co-products from the food industry to replace some of the compound feed in the diets of the animals. Figure 3 gives a simplified representation of the feed industry.

Compound feed companies deliver the bulk of the feed to farms in the intensive livestock production. The Dutch Association for Animal Feed Industry (Nevedi) estimates that, in The Netherlands for 2019, the direct on-farm delivered compound feed by its costumers (estimated to be approximately $95 \%$ of total deliveries) was 11.9 million tons [16]. Dutch compound feed production is estimated at around 14 to 15 million tons on an $88 \%$ dry matter basis [17]. SecureFeed reports 17.5 million tons of raw materials purchased by compound feed production members; this number will include raw materials for compound feed produced in The Netherlands but then exported [18]. There are around 120 compound feed companies in The Netherlands, with 5 of these exceeding 250 employees. Note that the 20 largest companies produce $88 \%$ of the total 13.5 million tons of compound feed produced in the country (pigs approx. $40 \%$; cattle approx. 30\%; poultry approx. $25 \%$; others approx. 5\%) [17]. Dutch feed companies are international important actors. According to TLN [17], 
of the top 10 compound feed producing companies in Europe, the top 4 in size of production volume are all of Dutch origin (Table 1). These companies are ForFarmers, Agrifirm Group, De Heus, and Nutreco/Trouw. This size ranking is based on total European production of these companies, in The Netherlands and abroad, as these companies have production facilities outside of the country.

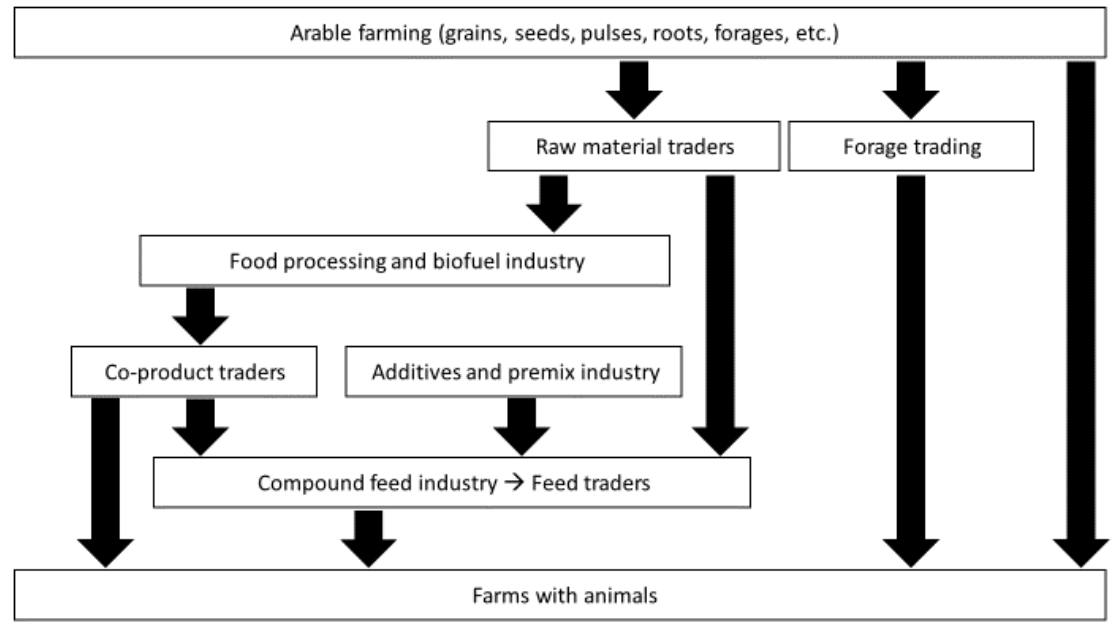

Figure 3. Simplified schematic representation of the feed industry (Based on OPNV website www. opnv.nl/index.php/en/2015-11-03-09-02-15/general-information (accessed on 1 March 2021)).

Table 1. The top 10 European feed-production countries and companies [17].

\begin{tabular}{cccc}
\hline Country & $\begin{array}{c}\text { Total Compound } \\
\text { Feed Production } \\
(\times \mathbf{1 0 0 0} \text { Tonnes, 2015) }\end{array}$ & Company & $\begin{array}{c}\text { Total Feed Volume, } \\
\text { ind. Ingredients } \\
(\times \mathbf{1 0 0 0} \text { Tonnes, 2015) }\end{array}$ \\
\hline 1 Germany & 23,345 & ForFarmers (NL) & 9100 \\
\hline 2 Spain & 22,273 & Agrifirm Group (NL) & 7056 \\
\hline 3 France & 21,092 & De Heus (NL) & 5950 \\
\hline 4 UK & 15,449 & Nutreco (NL) & 5900 \\
\hline 5 The Netherlands & 14,283 & DLG Group (DK) & 4140 \\
\hline 6 Italy & 13,665 & Agravis Raiffeisen (DE) & 4060 \\
\hline 7 Poland & 9308 & Avril Group (FR) & 3400 \\
\hline 8 Belgium & 6650 & Veronesi (IT) & 3150 \\
\hline 9 Denmark & 4190 & DTC (DE) & 2800 \\
\hline 10 Ireland & 3966 & Neovia (FR) & 2650 \\
\hline
\end{tabular}

The international and national feed market is very fragmented though. For instance, it is estimated that Dutch companies are responsible for approx. $2.5-3 \%$ of global compound feed production. The feed industry is an important stakeholder within the livestock sector. It is organized in different branches and associations that focus on different aspects such as representation and advocacy, feed safety, or research. Table 2 lists the most important associations of companies in the Dutch feed industry.

Table 3 gives a closer look into one of these associations and the type of actors involved, based on information from the annual report of SecureFeed. SecureFeed is a foundation aimed at guaranteeing safety of traded feed raw materials. Although this number might not be completely representative, it should include most of the companies involved in the animal feed chain in The Netherlands. The total volume of feeds and raw materials traded by these companies is 21.6 million ton on an $88 \%$ dry matter (DM) basis (This may include 
double counting for companies trading with each other, as well as feeds that are not only fed in The Netherlands but are exported).

Table 2. Associations of organizations active in the Dutch animal feed chain with number of members.

\begin{tabular}{|c|c|c|c|c|}
\hline Abbreviation & Name & English Name & Members & $\mathrm{Nr}$ \\
\hline SecureFeed & SecureFeed & SecureFeed & $\begin{array}{l}\text { Organizations buying and } \\
\text { trading feedstuffs }\end{array}$ & 385 \\
\hline FND & $\begin{array}{l}\text { Federatie Nederlandse } \\
\text { Diervoeder keten }\end{array}$ & $\begin{array}{l}\text { Federation of the Dutch } \\
\text { Animal Feed Chain }\end{array}$ & $\begin{array}{l}\text { Associations in the Animal } \\
\text { feed chain }\end{array}$ & 8 \\
\hline Nevedi & $\begin{array}{l}\text { Nederlandse Vereniging } \\
\text { Diervoederindustrie }\end{array}$ & $\begin{array}{l}\text { Dutch Association for } \\
\text { Animal Feed Industry }\end{array}$ & $\begin{array}{l}\text { Producers or traders of feed } \\
\text { to farmers. }\end{array}$ & 92 \\
\hline Het Comité & $\begin{array}{l}\text { Koninklijke Vereniging Het } \\
\text { Comité van } \\
\text { Graanhandelaren }\end{array}$ & $\begin{array}{l}\text { Royal Association, The } \\
\text { Committee of Grain Traders }\end{array}$ & $\begin{array}{l}\text { Companies active in the } \\
\text { agri-business }\end{array}$ & 130 \\
\hline OPNV & $\begin{array}{l}\text { Overleggroep Producten } \\
\text { Natte Veevoeders }\end{array}$ & $\begin{array}{c}\text { Discussion Group Producers } \\
\text { of Wet Animal Feeds }\end{array}$ & $\begin{array}{l}\text { Producers of wet animal } \\
\text { feeds (as food co-product) }\end{array}$ & 15 \\
\hline Hisfa & $\begin{array}{l}\text { Handelaren in Stro, Fourages } \\
\text { en aanverwante Producten }\end{array}$ & $\begin{array}{l}\text { Traders in Straw, Forages } \\
\text { and related products }\end{array}$ & $\begin{array}{l}\text { Traders in Straw, Forages } \\
\text { and related products }\end{array}$ & 100 \\
\hline MVO & $\begin{array}{c}\text { Maatschappij voor vetten } \\
\text { en oliën }\end{array}$ & $\begin{array}{c}\text { The Netherlands Oils and } \\
\text { Fats Industry }\end{array}$ & $\begin{array}{l}\text { Organizations active in } \\
\text { production, processing or } \\
\text { trade of plant and animal fats }\end{array}$ & $\sim 70$ \\
\hline VDDN & $\begin{array}{c}\text { Vereniging } \\
\text { Diervoederspecialiteiten en } \\
\text { Diergezondheidsproducten } \\
\text { Nederland }\end{array}$ & $\begin{array}{l}\text { Trade Association for } \\
\text { Manufacturers, Importers } \\
\text { and Suppliers of Animal } \\
\text { Feed Specialties in The } \\
\text { Netherlands }\end{array}$ & See name & $\sim 75$ \\
\hline NVG & $\begin{array}{c}\text { Nederlandse } \\
\text { Voedingsindustrie } \\
\text { Gezelschapsdieren }\end{array}$ & $\begin{array}{l}\text { Dutch Feed Industry for } \\
\text { Companion Animals }\end{array}$ & See name & $\sim 22$ \\
\hline VDN & $\begin{array}{l}\text { Vereniging } \\
\text { Diervoederonderzoek } \\
\text { Nederland }\end{array}$ & $\begin{array}{l}\text { Association for Animal } \\
\text { Nutrition Research, The } \\
\text { Netherlands }\end{array}$ & Compound feed industry & $\sim 5$ \\
\hline
\end{tabular}

Table 3. Number of companies that are a member of SecureFeed according to different categories and their procured tonnages of feed in 2019 (on an 88\% DM basis) [18].

\begin{tabular}{cccc}
\hline Segment & $\begin{array}{c}\text { Number of } \\
\text { Companies }\end{array}$ & $\begin{array}{c}\text { Feed Purchased (in 100 } \\
\text { Tons 88\% DM Basis) }\end{array}$ & \% of Total \\
\hline Forage traders & 114 & 645 & 3.0 \\
\hline Special feed traders & 51 & 90 & 0.4 \\
\hline $\begin{array}{c}\text { Compound feed and raw } \\
\text { material traders }\end{array}$ & 112 & 1815 & 8.4 \\
\hline Compound feed producers & 62 & 17,507 & 81.2 \\
\hline Special feed producers & 10 & 90 & 0.4 \\
\hline Feed producers & 15 & 146 & 0.7 \\
\hline Moist co-products traders & 21 & 1264 & 5.9 \\
\hline Total & 385 & 21,556 & 100 \\
\hline
\end{tabular}

In this section, so far, we have sketched the organization of the feed industry that is structuring the livestock and particularly the feed sector in The Netherlands (and beyond). Next, we introduce the diets of Dutch livestock and identify some sustainability issues. 


\subsection{The Menu}

Cow diets (i.e., dairy cows) are largely composed of forages, which are mainly farm grown with a small part of it bought by the farmer from other farmers or through forages traders. Dairy farmers using a feeder wagon might use some wet co-products, premixes, concentrates, or single ingredients to mix their diet. Dairy diets mixed in this way often are a "partial mixed ration", where the basis of the diet is fed in the mix at the feeding gate. The compound feed supplement is then often fed in automatic compound feed dispensers that distribute this feed based on the cow's milk production. This is different than the "total mixed ration" concept where all feeds are fed in one mix, which we estimate that is used in about $20 \%$ of Dutch dairy farms.

Pig diets are mainly composed of compound feeds, but there is also a significant use of co-products and some single ingredients. Chickens are mainly fed on compound feed, with some single ingredients used (see Table 4).

Table 4. Relative composition of the total diet for cows, pigs, and chickens (88\% DM basis) [16].

\begin{tabular}{ccccc}
\hline & Forage $\%$ & $\begin{array}{c}\text { Compound } \\
\text { Feed \% }\end{array}$ & $\begin{array}{c}\text { Wet } \\
\text { Co-Products \% }\end{array}$ & $\begin{array}{c}\text { Single } \\
\text { Ingredients \% }\end{array}$ \\
\hline Cows & 74 & 20 & 4 & 2 \\
Pigs & 0 & 73 & 18 & 9 \\
Chicken & 0 & 77 & 0 & 23 \\
\hline
\end{tabular}

Regarding co-products, for instance, pigs get in their menu a total of 4.9 million tons (Mt) of co-products of grain (wheat starch, brewery grains, and yeast, etc.) and potato (e.g., fibers, steamed peals) processing industries, sugar industry, whey and milk products, fermentation and yeast industry, and other sources such as grain energy, soya, or beverage and other type of products [19].

The ranking of the total estimated ingredient use for animal feed is wheat $(4.1 \mathrm{Mt})$, maize $(2.9 \mathrm{Mt})$, soya bean products $(2.1 \mathrm{Mt})$, barley $(1.7 \mathrm{Mt})$, palm kernel expeller $(0.9 \mathrm{Mt})$, beet pulp $(0.9 \mathrm{Mt})$, rapeseed products $(0.8 \mathrm{Mt})$, sunflower seed products $(0.6 \mathrm{Mt})$, and others $(0.3 \mathrm{Mt})$, resulting in a total of 14.4 million tons of ingredient used [20,21]. Not all these ingredients are primary ingredients; Nevedi [16] claims that about $42.7 \%$ of ingredients used in Dutch compound feed are co-products. This of course does depend on the definition of a co-product. Furthermore, not all ingredients are fed to all animal species to the same amount. Ingredients such as palm kernel expeller are likely to be fed more to ruminants than to monogastric animals. Wheat, maize, and barley will be fed relatively more to pigs and chickens, although these can also be used in ruminants (mainly maize). Detailed information on the dietary composition on a national basis is hard to obtain. The ingredient composition of compound feeds is determined at the level of the individual compound feed company, or even of the individual farm, based on least cost formulation of compound feeds or total diets as influenced by the supply and cost of the ingredients. With changing prices and raw material availability, the amounts of the different raw materials used fluctuate.

\subsection{Sustainability Issues}

The high input and export-orientated Dutch livestock production poses some circularity challenges. For instance, feed resources have to be imported to be able to sustain the Dutch number of animals. Just $11.6 \%$ of raw materials for compound feed are produced in The Netherlands, $55.6 \%$ in geographical Europe, $20.5 \%$ in South America, $7.6 \%$ in North America, and 4.7\% in Asia [16]. The Royal Dutch Grain and Feed Trade Association 'Het Comité' estimates similar numbers, at 7\%,59\%, 19\%, 9\%, and 5\%, respectively, with an additional 1\% coming from Oceania for 2015-2018 [20]. This creates business opportunities in these regions but also put pressure on land use [22,23] and food production [24]. Moreover, transporting these resources over long distances generates ecological problems by the usage of non-renewable fossil-fuel and the subsequent GHG emissions [22]. 
All these feedstuffs are transformed by animals into, e.g., meat, milk, eggs, heat, methane, and $\mathrm{CO}_{2}$, and the remaining are also excreted as manure. The relative high number of farm animals produce much more manure than the country can handle/usefully apply alone. It is estimated that a total of 74,602 million $\mathrm{kg}$ of Dutch manure was excreted in 2019 (Source CBS Statline June 2020). This generates a surplus of minerals (mainly nitrogen and phosphorus) exceeding the limits of the local ecosystems $[7,8,23,24]$. Nitrogen deposition (for instance as the result of ammonia emissions from livestock production) is a problem for natural protected areas. European and national regulatory frameworks have not been able to solve this problem. In 2019, Leenstra et al. report that there is a phosphate surplus of $8 \mathrm{~kg} / \mathrm{ha} /$ year and a nitrogen surplus of $131 \mathrm{~kg} / \mathrm{ha} /$ year [25]. The Dutch government reports that in 2020, the two main sources of nitrogen into the agriculture were concentrates (415 million kilogram) and synthetic fertilizers (220 million kilograms), and that the nitrogen surplus was 307 million kilograms (https:/ / www.cbs.nl/ nl-nl/nieuws / 2022/04/stikstofoverschot-landbouw-in-2020-iets-toegenomen, accessed on 1 January 2022). In May 2019, the highest administrative court of The Netherlands judged the Dutch regulatory framework as inefficient to meet the European directives. Subsequently, expansion permits for farms and also infrastructure and housing permits were stopped. A massive protest of farmer groups followed; the media and policy makers frame this impasse as "the nitrogen crisis."

Globally, livestock is an important source of GHG emissions [3,5,6]. For instance, it is estimated that around $65 \%$ of the global warming potential of pig production systems is caused by feed production [26]. In The Netherlands, feed production, together with enteric fermentation, manure management, and fossil fuel energy use are the major sources of GHG emissions. It is estimated that in 2015, livestock was responsible for $9 \%$ of the total GHG emissions (i.e., $18 \times 10^{9} \mathrm{~kg} \mathrm{CO}_{2}$-equivalent) of The Netherlands [23]. Note that because of the large import of feed, Dutch livestock is responsible for a similar amount of emissions abroad. Post et al. [23] estimate that the GHG emissions inside and outside of The Netherlands amounts to $42 \times 10^{9} \mathrm{~kg} \mathrm{CO}_{2}$-equivalent.

Most of the grass and maize is produced in The Netherlands. A large proportion of the other feed stuffs are produced outside of the country. Around two thirds of the national land area are used for agriculture. Post et al. [23] estimate that in 2015, the national land use related to livestock was $14,000 \mathrm{~km}^{2}$ and globally $26,000 \mathrm{~km}^{2}$. Moreover, agricultural production, including the production of feed related raw materials, is one of the major drivers of deforestation [27]. It is estimated that 43 million hectares have been deforested between 2004 and 2017 [27]. Soya production and consumption is one of the drivers of this process. The private sector agreement known as the Soya Moratorium of 2006 requires increasingly more soya in the Amazonas regions to be responsible certified. Grain traders agreed not to purchase soya produced on recently deforested areas (https: / / responsiblesoy.org/?lang=en (accessed on 1 January 2022)). Dutch feed industry claims that all the soya used is (by certification) deforestation-free [28]. However, some argue that the pressure might be exported outside of the Amazonas, and the damage might have been caused already before 2006 [27,29]. In the EU, The Netherlands is the largest importer of soya, and it is the largest importer of Brazil's soya. A good part of the imported soya is directly handled and exported at the Port of Rotterdam or exported after having been processed. Moreover, despite the efforts of soya certification standards such as the Round Table on Responsible Soy (RTRS), some report that these initiatives are not effective in "protecting the rights and access of local communities to land and water" [30].

Another important issue is the competition between food and feed production. Some argue that the footprint of feed usually does not include the possible competition with food [31]. This concerns the competition for biomass or other natural resources such as fertile soil [4], or clean water [32]. As argued, mainly because of the dependence on the import of feed, a large share of the pressure occurs outside of The Netherlands.

There are also some socioeconomic challenges ahead. As aforementioned, the Dutch feed industry is globally oriented and a key actor within the livestock chain. At the national 
level, it is estimated that feed represents between 50 and $77 \%$ of the annual costs of a pig farmer [33]. At this socioeconomic level, the large share of imported feed not only has global environmental impacts but also influences the global governance of markets and chains. Dutch feed companies are influential actors within the international chain production/consumption of soya, meat, egg, and dairy products [34]. Virah-Sawmy et al. [34] show that the sustainability-policy instruments formulated and implemented by leading upstream and downstream actors in the global soya-meat value chain differ and do not meet global challenges as land appreciation or the access to affordable meat. They [34] argue that the linear and vertical integration of this chain ought to be reorganized into a network form of governance involving social interaction, information sharing, trust building, and shared vision for transitioning food systems towards higher levels of sustainability.

Dutch livestock contributes to produce food and economic welfare; at the same time, it generates many sustainability issues. The concept of circularity is now being implemented and initiatives are organized to improve the sustainability of the Dutch livestock sector.

\section{A Circularity Assessment Framework-'Squaring the Circle'}

Etymologically, the word circularity derives from the Latin 'circularis' and then from 'circulus' which is related to the geometric figure, the circle. Different cultures have used this shape to mean, among others, wholeness and perfection as opposed to the supposed imperfection of linearity, motion, and change [35]. However, some have argued that western cultures usually try to rationalize the 'natural' perfection of the circle which, in a way, is based on 'irrational' values such as $\pi$ by 'squaring the circle' [35].

After World War II, the concept of circularity was elaborated within the context of natural resource use in productive processes denoting the reduction or avoidance of waste and trade-offs [36,37]. In the last decades the concept has acquired broader connotations, as it has been implemented in other fields such as policy making and the economy, and it has achieved a more holistic and sustainability-like meaning [10,31,38,39]. A search on the internet for 'circular economy' delivered 20,570 hits in 2008, 5.74 million in 2019 [39], and approx. 183 million in (November) 2021.

In line with other countries, the Dutch government is aiming for a circularity transition, both in the economy as a whole and in agriculture $[13,14]$. In this research we have identified some key initiatives that are currently being testing, developing or producing circular livestock feed in The Netherlands (Section 4). To gain a better understanding of the role that they play in the circularity transition, we evaluate these feed categories according to a set of criteria which are based on central principles and aspects of circularity. Next, we summarize the principles of circularity as elaborated by the Ellen MacArthur foundation, then we report the interpretation by the Dutch government of some of those principles and their operationalization into assessment criteria. Then, we focus on some ecological principles of circularity related to livestock and agriculture (our focus here) that have been formulated by scholars and use them as a valid starting point for our framework. Ultimately, we question this exclusive focus on ecological principles and propose human and animal-oriented dimensions of circularity. We conclude this section by operationalizing the four criteria that we have used to assess some circularity feed initiatives.

\section{Circularity Criteria}

The Ellen MacArthur foundation argues that transitioning to a circular economy not only implies the reduction of the negative effects of the linear economy but also means " $a$ systemic shift that builds long-term resilience, generates business and economic opportunities, and provides environmental and societal benefits" (https:/ / www.ellenmacarthurfoundation.org/ circular-economy / concept (accessed on 1 December 2019). This charitable organization proposes, therefore, three fundamental principles of circularity:

- "Designing out waste and pollution." The foundation claims that this principle can be achieved by decoupling economic activities and welfare from the depletion of finite resources. 
- "Keep products and materials in use."

- " "Regenerate natural systems," implying that not only protective practices are required but also that we might actively improve the environment.

These principles are formulated from a natural resource perspective. Some [39] have claimed that this is why this [40] and other similar approaches, such as the one formulated by the European Community [10], have failed to address some social and sustainability issues of circularity.

As mentioned, the Ministry of Agriculture, Nature and Food Quality of The Netherlands envisions and facilitates a transition towards a circular agriculture [14]. In the 'vision realization plan' the Ministry argues that this vision is not a blueprint. Therefore, some assessment criteria/questions for decision makers have been developed for the evaluation of projects, policies, interventions, etc. [13].

- "Do they contribute to closing cycles, to reduce emissions and to reduce biomass wastage throughout the food system?

- With regard to fisheries, does it contribute to sustainable stock management without damaging the natural environment?

- Do they strengthen the socio-economic position of the famer in the supply chain?

- Do they contribute to the climate task for agriculture and land use?

- Do they enhance the appeal and vitality of the countryside and contribute to a thriving regional economy?

- Do they benefit ecosystems (water, soil, air), biodiversity and the natural value of the farming landscape?

- Has animal welfare been considered?

- Do they contribute to the recognition of the value of food and to strengthening the relationship between farmers and citizens?

- Do they strengthen the position of The Netherlands as a developer and exporter of integrated solutions for climate-smart and ecologically sustainable food systems?"

In addition to these assessment criteria, the Ministry argues that "food safety and quality always apply as baseline conditions" [13]. These guidelines are interesting and specific, though not compulsory, for decision-makers and give a sense of the articulation of the concept of circularity from a governmental perspective. The bottom line is to protect the environment by closing material and biogeochemical cycles without losing economic wealth. However, they are formulated from within the Dutch geographical borders, while livestock feed practices are global.

Currently, awakened by the governmental vision and financing, there is a lively debate in The Netherlands regarding circularity [41-44]. Within academia, the concept is being articulated and applied to the Dutch context considering also the open and global oriented production/consumption systems. De Boer and van Ittersum [31] elaborate three main principles regarding circular food production, namely (quoted literally):

- $\quad$ "Plant biomass is the basic building block of food and should be used by humans first

- By-products from food production, processing and consumption should be recycled back into the food system

- Use animals for what they are good at, transforming human inedible plants and organic matter into high quality human edible proteins"

In subsequent works, de Boer and colleagues [44,45] (https:/ / www.wur.nl/en/showlongread/Re-rooting-the-Dutch-food-system-from-more-to-better.htm (accessed on 1 April 2021)) have further elaborated these principles. We believe that this is a valuable basis as it builds on the circularity tradition and it is specific for livestock and agriculture production, our focus here. Next, we focus on three circularity principles as elaborated by de Boer and colleagues on which we build our framework.

- Safeguard the health of (agro)ecosystems. The aim here and the core of the circularity approach is conservation and restauration of ecosystems to achieve clean soil, air, and water. This might imply the deployment of agricultural systems that produce a 
minimal amount of, or no, greenhouse gas emissions at all, or that do not produce excessive nutrients. It might also imply zero deforestation. These researchers also propose systems that might fit this criterium such as agroforestry, intercropping, and the like.

- Avoid non-essential products, and losses and waste of essential ones. The idea here is that 'avoiding' is better than recycling and should precede this. In this way, upstream production processes and associated impacts are avoided.

- Use biomass effectively, recycle inevitable and unavoidable biomass streams (Please note that de Boer et al. formulate these as two separate principles, (1) effectively use and (2) recycle. We think that it makes sense to combine them. Moreover, they propose other related and integrable principles that are beyond the scope of this research. For instance, minimizing renewable energy usage in productive processes, which implies avoiding energy use of non-renewable sources [44]). The objective here is to employ agricultural fertile soils or natural waters primarily for the production of food, rather than for feed or other less relevant commodities such as biomass or biofuels, in the light of poverty and hunger and the deterioration of nature by productive activities. So, the argument goes, to feed livestock with fish meal is not a solution within this circularity principle [31]. This is a key principle regarding feed indeed. In a vision regarding the Dutch future of food, de Boer et al. (www.wur.nl/en/show-longread/ Re-rooting-the-Dutch-food-system-from-more-to-better.htm (accessed on 1 January 2021)) (see also [2]) argue that

"[...] fertile arable land is no longer used to produce feed crops for animals. Plant biomass is the primary source of food for humans." [... "By-products that cannot be prevented, eaten by humans or are not needed to restore or conserve soil fertility are given to farm animals (including farmed fish or insects), who can convert them into valuable food and manure. A circular food system will be the new paradigm as valuable nutrients are recycled from soil, water and the atmosphere into living organisms and back, and across farms and regions."

Livestock can play a key role in transforming, for instance, unavoidable by-products that result from the production of food and that are non-humanly edible into human edible proteins [1]. Livestock products themselves can also be 'recycled' into the production system. An evident example is the application of manure as fertilizer instead of using non-renewable inorganic fertilizers such as phosphate rock that has to be mined $[46,47]$ or nitrogen, which production is energy-intensive [46,48,49]. Another example is the recycling of slaughter remains a source of protein in feed that, until recently, has been however restricted in the EU for public health reasons dating back to the bovine spongiform encephalopathy (BSE) crisis in the 90's [33].

These circularity principles are formulated from a 'planet' perspective, most probably from a viewpoint that the carrying capacity of the earth is a basic requirement of sustainability, before people and profit. However, we know that also cultural and economic aspects are central to sustainability and circularity [36,37]. Some have claimed that a focus on ecosystems is also common in the wider field of sustainability. Van der Linden et al. [50] use the environmental, economic and social dimensions of sustainability to assess models that are used for evaluating the "sustainability consequences of innovations and policies for European livestock farms". They conclude that just 33\% of the models cover all three sustainability dimensions. Social issues were the topics left out the most when assessing livestock sustainability.

In this context, Corona et al. [51], in their analysis of the metrics of circularity, argue that the methods to assess circularity that are reported in the literature are mainly based on the following five requirements, quoted literally:

- $\quad$ "Reducing input of resources, especially scarce ones

- $\quad$ Reducing emission levels (pollutants and GHG emissions)

- $\quad$ Reducing material losses/waste 
- Increasing input of renewable and recycled resources

- Maximising the utility and durability of products"

Neglected aspects are related to social fairness and economic wellbeing, they argue. They propose three additional criteria to address this blind spot, quoted literally:

- "Creating local jobs at all skill level

- Value added creation and distribution

- Increase social wellbeing"

We agree with these insights that social aspects are also relevant to circularity, certainly if governmental organizations, as it is the case in The Netherlands, propose circularity as central concept to develop agriculture. Therefore, to the three ecological principles aforementioned, here we add a social dimension: (The circularity principle of) Fairness and accessibility. Quantitatively speaking, in terms of proteins and volumes, right now, there is enough food to feed the world [52,53]. However, concerning food, accessibility and sovereignty are important economic and political issues at stake [54]. In our view, ecological claims regarding livestock (feed) production have to be considered together with social issues such as food availability and cultural practices. Food is more than a quantity of human edible proteins; it is a key cultural element defining societies (fast food, 'haute cuisine', 'halal' meat, pastoral societies, etc.). Social aspects of circularity include economic issues, a need to decouple economic profit from activities that contribute to the depletion of nature. The concept of de-growth, for example, has been proposed to address this issue $[39,55]$. Furthermore, circular initiatives ought to improve the economic wellbeing by, for instance, maintaining or improving employment (at local or international level). Consequently, in line with other authors [51,56] we integrate social (including economic) and ecological dimensions of circularity in the analysis.

Also, since the focus here is on feed, an animal-centred principle is integrated. A less elaborated issue concerning circular changes are the possible impacts on animal welfare. Welfare concerns the physical and mental condition of animals along their lives and deaths $[57,58]$. An important factor influencing the welfare (and productivity) of livestock is feed [59]. Some argue that the reorganization of agriculture and livestock production along circular principles will also solve some animal health and welfare issues [31]. From a circularity resources perspective, livestock systems that hold high welfare standards might maintain also high productive and profitability levels [60-62], lower use of antibiotics and other antimicrobial and veterinary medicines and the subsequent effects on public health (e.g., antimicrobial resistance) and the accumulation of antimicrobial resistance or medicine residues in the environment $[63,64]$.

Scholars claim that for evaluating circularity performance, macro-indicators are better developed than indicators for the micro-level [51,56]. The circularity principles (macro) are operationalized here as evaluation criteria. We do not pretend to say that feed initiatives ought to comply with $100 \%$ of these (and each of these) principles. We rather use them here heuristically to conduct a coherent study of feed categories within the context of the circularity transition. Moreover, regarding the categories and initiatives here addressed, we elaborate on some of these principles, mainly the most relevant for that particular category or for those for which information is available.

The criteria that structure our evaluation are operationalized as follows-circular feed practices ought to

- Safeguard the health of ecosystems. Circular feed categories contribute to achieve or maintain healthy soils and clean air and water. To evaluate key categories, we focus here on their possible effects on contamination, biodiversity protection (think of ammonia emissions), and minimizing greenhouse gas emissions.

- Avoid the production of unnecessary products and use/recycle biomass effectively (food vs. feed). There are many relevant related issues regarding this principle. For example, the overall necessity of a specific feed source, are there other possible feed sources which now better meet the current feed needs and circularity demands? To answer 
this question, one should focus on the whole food system and chains; this is, however, beyond the scope of this research. Here, we evaluate circularity feed sources by focussing on some issues regarding the usage and reusage of biomass and the possible competition of feed with food for land and other resources.

- Fairness and accessibility. Circular feed practices are fair at the social and economic level contributing to social wellbeing. Here, we focus on the ability of feed categories and initiatives to create or maintain employment at different skill levels, generate economic profit while guaranteeing the current, in The Netherlands, accessibility (relative low prices) to (quality and healthy) food. When required, some general observations of possible impacts at the global level might be integrated.

- Animal health and wellbeing. Feed is aimed at feeding animals, so a baseline condition and assessment criteria are that the feeds and practices produced do not negatively affect farm animal health and wellbeing. Neither do they affect negatively human health.

\section{Circularity Feed Categories and Initiatives in The Netherlands}

Through a desk study, a number of feed categories have been identified. These categories have been selected mainly according to the following criteria: (1) there are already some initiatives within this category that are funded/organized from a circularity perspective or claim (2) in The Netherlands; and (3) there are already reports or scientific literature, or policy interventions addressing this category, suggesting that these initiatives are not just part of a prospective policy or sectorial initiative but that they are, to a certain extent, stabilized. The categories here addressed are not all the categories that fit the current feed circularity narrative in The Netherlands. We find other categories such as food-industry waste or leftovers from fisheries and fish farming that we do not include here because these are already well-organized feed chains [65]. Moreover, other categories are not included because they are still in a tentative stage, such as the production of proteins from sewage water (Power to Protein (https: / / www.powertoprotein.eu/ (accessed on 1 October 2021)).

Insects are not included either. The Dutch Association of Insect Producers (Venik) represents the interests of the sector. Since August 2021, at the European level, a new amendment (Commission Regulation EU 2017/893 9) has come into force authorizing "the use of processed animal protein derived from insects and compound feed containing such processed animal protein for feeding aquaculture animals", poultry, and porcine livestock. Though promising, we do not evaluate this here because of the lack of space and because this is a well-documented category (see, e.g., Journal of Insects as Food and Feed [66,67]).

Another interesting category that was not included concerns the slaughter remains produced in abattoirs and the cadavers of farm animals that died at the farm level. For example, in The Netherlands, the total amount of carcasses of livestock occurring at farms, in 2020, is estimated at $130,296,000 \mathrm{~kg}$. Of this, approx. 60,781,000 kg comes from cattle, $43,804,000$ from pigs, 21,532,000 from poultry, and 4,179,000 from other farm animals (Vermeij, personal communication, November 2021). Hereby, one could add carcasses coming from hobby animals such as horses, ponies, dogs, etc. Moreover, we have also the remains produced at the abattoirs that are classified as low-risk material and that do not fit or are not intended for human consumption because of current commercial considerations, e.g., hides, hair, and other parts. In 2010, Vermeij and Bosma [68] estimated that approx. 1500 million $\mathrm{kg}$ by-products were produced in the abattoirs, some of which were processed as pet food and mink feed [68]. In 2020, a total amount of approx. 800 million $\mathrm{kg}$ was produced (Vermeij, personal communication, September 2021 and January 2022). From a nutritional perspective, processed animal proteins are a high quality feed source containing highly digestible nutrients such as amino acids and phosphorous and have a high content of vitamins. Since 2001, in order to prevent BSE expansion leftovers form cattle have been banned as feed, the EU also restricted the processing of other animal waste streams such as meat, hides, and bones. Nevertheless, some of these streams were allowed as feed for fish and pets [69]. A change has been forced due to, among other factors, the 
discussions regarding deforestation for soya production and biomass efficiency usage (i.e., circularity). In August 2021 the amendment to this regulation (Annex IV to Regulation (EC) No 999/2001) (https:/ / op.europa.eu/en/publication-detail/-/publication/987745 10-80ae-11eb-9ac9-01aa75ed71a1/language-en (accessed on 1 September 2021)) came into force allowing the processed animal protein of porcine in poultry feed and of poultry in pig feed. An open question here is whether in the near future (a circular economy) these high-quality proteins will remain labeled as 'waste'.

In the following sections we evaluate the following feed categories:

- Food waste;

- Seaweed/macroalgae;

- Localized production and alternative plant-based feed sources.

\subsection{Food Waste}

This category concerns the food that is produced for human consumption, but that is wasted at households, restaurants, and the catering industry in The Netherlands. In this study, garden waste from the 'kitchen and garden waste' (from the Dutch 'GFT = groente-, fruit- en tuinafval') is not included in this category. In The Netherlands this (GFT) 'waste' is usually collected at the household level and composted; the compost can be used on the land as fertilizer and to improve soil conditions. We leave gardens' biomass out of this study, among other reasons, because this also might contain manure from pets and other domestic animals, meaning that a separation/processing step(s) must be implemented before this waste can be used as a feed source. The value of gardens' biomass ought to be considered within the circularity transition, of course; however, this issue is beyond the scope of this research.

FAO estimated that the per capita food wasted by consumers in Europe and North America is about $95-115 \mathrm{~kg}$ per year [70]. Currently, in the United States, it is estimated that $32 \%$ of food is wasted at the household level [71]. In the EU, it is estimated that about 102.5 million tonnes of food were wasted in 2015 from four main waste streams: households ( $42 \%)$, manufacturing $(39 \%)$, food service/catering industry $(14 \%)$, and retail (5\% of food waste) [33]. In The Netherlands, catering and restaurant food waste is estimated as 51 million kg yearly, which is $14 \%$ of all the country's food waste (Samen Tegen Voedselverspilling I Nieuws: Horeca Food Waste Challenge (accessed October 2021)), and a person throws away more than $50 \mathrm{~kg}$ food per year, a total of 800 million $\mathrm{kg}$ (Waarom minder voedselverspilling goed is voor iedereen (rabobank.com) (accessed on 1 October 2021)). Food waste has a high nutritional value, see Table 5.

Table 5. Bioactive compounds and major components of food waste. Adapted from review study [72].

Food waste was dried in a drum type dryer at $115 \pm 2{ }^{\circ} \mathrm{C}$ crude protein $(\mathrm{CP})(25 \%)$, salt content $(3.28 \%)$, ether extract (EE) $(17.3 \%)$

Restaurant and apartment complex areas The majority of the essential amino acids, such as methionine and lysine, were considerably lower in quantity than that of a corn and soybean $\operatorname{mix}(60 \%: 40 \%$ ratio).

Food waste contained CP (27.6\%), ash (14.56\%), calcium $(1.09-1.25 \%)$, phosphorus $(0.16-0.30 \%)$, $\mathrm{K}(0.56-0.76 \%), \mathrm{Mg}(0.1-0.2 \%), \mathrm{EE}(9.12 \%)$, oleic

Commercial and residential locations acid $(30.63 \%$ of $\mathrm{EE})$, linoleic acid ( $25.5 \%$ of $\mathrm{EE})$, and linolenic acid (3.03\% of EE) and had polyunsaturated fatty acid/saturated fatty acid ratio $(0.78), \mathrm{n}-6 / \mathrm{n}-3$ fatty acid ratio (7.94).

Swill has been a traditional feed for pigs and contains the right nutritional elements for feed production [33,72]. It could contribute, therefore, to the reduction of the environmental 
impact of livestock production. However, this practice is banned in the EU because of public health and safety issues, such as episodes of foot and mouth disease, the bovine spongiform encephalopathy, and the African swine fever (EC regulation 1774/20020). The circularity transition might enable a revision of this situation, as food waste can provide an interesting feed for livestock and avoid competition between food and feed production [73].

\subsubsection{Evaluation}

Safeguard the Health of Ecosystems

Food waste can be defined as low-opportunity-cost feed. According to van Zanten et al. [1] (see also [31]), under certain circumstances, consumption of food produced by animals that are fed with this and other low-opportunity-cost feeds saves up to one quarter of global arable land when compared to consumption of plant-based food. Moreover, zu Ermgassen and colleagues [33] argued that with current technologies, one fifth of agricultural land could be saved by consuming animals fed with food waste.

Using the estimated 800,000 tons of food wasted by consumers in The Netherlands with an estimated 20\% DM content would mean a production of approx. 180,000 tons of feed ( $88 \%$ DM content). This is, however, equal to about $1.5 \%$ of total Dutch compound feed production.

Avoid the Production of Unnecessary Products and Use/Recycle Biomass Effectively (Food vs. Feed)

By using food waste to feed animals, nutrients are recycled into the food system that would otherwise be lost [31]. Moreover, globally, swill could replace 8.8 million tons of grain that is currently fed to pigs and which is suitable for human consumption [33]. However, one wonders for how long Dutch households will throw away as much food as they do today. Avoiding and reducing food-waste ought to be the priority, of course, while unavoidable food waste can be upgraded as livestock feed.

\section{Fairness and Accessibility}

It is difficult to envision how the use of food waste as feed will affect, e.g., the price of pork. Zu Ermgassen et al. [33] estimated that between 55 and 72\% of the costs of pig production are related to feed. Using low-cost swill as we know it today, especially in pig farms around urban areas, the argument goes, might reduce production costs significantly [33]. However, separation or/and processing steps will be required to avoid public health issues [74], which might increase, in their turn, food production and consumption costs.

\section{Animal Health and Wellbeing}

The main reason why feeding swill is not allowed in the EU is the risk of disease transmission for animals and humans (e.g., foot and mouth disease, African swine fever, classical swine fever, salmonellosis, toxoplasmosis, and bovine spongiform encephalopathy) [74]. Most probably, the foot and mouth disease episode started in 2002 in the UK by feeding illegal uncooked food to pigs [33]. Since then, the recycling of food waste as swill has been banned in the EU. Therefore, the use of swill as feed source, if/once allowed, will be strictly regulated and organized around a processing step. In Japan, South Korea and Taiwan, strict regulatory frameworks have been organized to allow the centralized processing (heat treatment) of waste to produce feed and, so far, no disease outbreaks have occurred [33].

\subsection{Seaweed/Macroalgae}

Seaweed production has attracted attention as it could contribute to an increase in new sustainable raw materials in The Netherlands; it can, amongst others, provide protein and carbohydrates for animal diets [75]. Moreover, it has some advantages over arable land-based cultivation, due to its high biomass productivity and the use of salty water [76]. 
Currently, however, a small amount of seaweed is cultivated in The Netherlands. Apparently, large-scale seaweed cultivation is not (yet) viable in Western Europe. In Europe, only 1554 tonnes of seaweed (fresh weight) were produced in 2016, while a total of $30,139,388$ tonnes were produced worldwide $[77,78]$. In The Netherlands, some projects have started aimed at achieving higher economic rewards and lower production costs (See, e.g.,: MIP Seaweed for food and feed-WUR (https:/ / www.wur.nl/nl/OnderzoekResultaten/Onderzoeksprojecten-LNV/Expertisegebieden/kennisonline/MIP-Seaweed-forfood-and-feed.htm (accessed on 18 February 2022)); Voorlopig beeld uit project Zeewier in een gezonde melkveehouderij—WUR (https:/ /www.wur.nl/nl/Onderzoek-Resultaten/ Onderzoeksinstituten/livestock-research/show-wlr/Voorlopig-beeld-uit-project-Zeewierin-een-gezonde-melkveehouderij.htm (accessed on 18 February 2022)); Pro Seaweed (http: / / www.proseaweed.eu/ (accessed 1 November 2021)). This is performed by paying attention to a circular approach, local production, and a multidisciplinary approach of the production chain. So far, however just a few companies cultivate seaweed in approx. 10-15 hectares of the Dutch coastal area (Nauta, personal communication, January 2022).

Many different species can be found, varying in their amino-acid pattern protein, fat, and carbohydrate content. Differences between species can be caused by the timing of harvesting and geographical and environmental factors [79]. To gain an impression of the overall potential of seaweed for feed, this category concerns here seaweed, i.e., either brown (Phaeophyceae), red (Rhodophyceae), or green (Chlorophyceae) macroalgae that can be used for feed.

\subsubsection{Evaluation}

Safeguard the Health of Ecosystems

The Netherlands is characterized by a delta and coastal geography. Seaweed can be cultivated inland and offshore. Inland production facilitates the control of production conditions, but it is restrained by space and it is associated with higher costs [80]. The offshore production of seaweed does not rely on large amounts of agricultural land [78] and can reduce the pressure on forest and land ecosystems (land use and land use change). Additionally, research suggests another positive effect: the production of seaweed in coastal areas can reduce eutrophication processes [81].

However, offshore seaweed cultivation brings an impact to coastal and ocean ecosystems as offshore seaweed farms will bring noise and artificial structures and materials with associated problems [82]. Campbell et al. [82] summarized high risks associated with seaweed cultivation that have to be considered/avoided and monitored: "genetic depression of natural algal populations, facilitation of algal diseases, changes to the physical environment through alteration of hydrodynamic regimes, entanglement of mega-fauna, and depletion of natural nitrogen pools in enclosed water bodies."

Some types of red seaweeds naturally produce bromoform $\left(\mathrm{CHBr}_{3}\right)$. Research is conducted to explore its inhibiting potency regarding enteric methane emission [83,84], which is the main source of GHG from ruminants. Bromoform is, however, a toxic substance that might be hazardous for animals and humans, which is why research is being conducted to understand the presence of bromoform, e.g., in the urine, faeces, milk, and animal tissues of dairy cows [85]. Nevertheless, it is reported as a feed additive with potency for methane emission mitigation [84].

Besides, Koelsling et al. [86] conducted a life cycle assessment (LCA) study for the production of seaweed in Norway; among others, they concluded that with the current state-of-the art, seaweed protein has a Global Warming Potential (GWP) 4 times higher than soya protein from Brazil. Improved production processes (e.g., drying seaweed) that reverse this situation are required [86]. Moreover, Slegers and colleagues [87] conducted a LCA research on the current state-of-the art cultivation of seaweed (S. latissima) (for use in vegetarian burgers) "in the Dutch Exclusive Economic Zone of the North Sea." They conclude that the current cultivation impact which varies between 10 and $52 \mathrm{~kg} \mathrm{CO}{ }_{2} \mathrm{eq} / \mathrm{kg}$ wet weight seaweed, being the (time and) vessels used for the transportation of the cultivation modules 
and for harvesting the most important (70-75\% impact) GWP of the production system [87]. This study indicates that an optimalization of production (transport, increasing yields and lifespan of materials) is required [87], potentially reducing the impact to $0.2 \mathrm{~kg} \mathrm{CO} \mathrm{CO}_{2} \mathrm{eq}$ per $\mathrm{kg}$ wet weight. At a 20\% DM content, this would mean a footprint of $1 \mathrm{~kg} \mathrm{CO} 2 \mathrm{eq}$ per $\mathrm{kg}$ $\mathrm{DM}$; this is substantially lower than current numbers given for soya bean meal at $\sim 5 \mathrm{~kg}$ $\mathrm{CO}_{2}$ eq per $\mathrm{kg} \mathrm{DM}$, but slightly higher than maize $(\sim 0.7 \mathrm{~kg} \mathrm{CO}$ eq per $\mathrm{kg} \mathrm{DM})$ and wheat (0.5 kg CO 2 eq per $\mathrm{kg} \mathrm{DM}$ ) according to the calculation method in van Dijk et al. [88]. This can make of seaweed a sustainable 'food' ingredient with a global warming potential in the range of current cereal grains, but lower than soya when land use change is included in the calculation.

Avoid the Production of Unnecessary Products and Use/Recycle Biomass Effectively (Food vs. Feed)

Seaweeds might have a high nutritional value $[87,89]$. Moreover, seaweed contains elements such as vitamin B12 and carotenes that generally are delivered by animal-based products [87]. However, seaweed can have a high salt content, which can limit application in food [87] and feed [75]. Although seaweeds are used for culinary purposes [90], there is still a small market for seaweed products [80,87]. The current production costs and environmental impacts make a production of seaweeds for food more probable than for feed, although upscaling and optimalization of the production processes might eventually shift this situation [80].

\section{Fairness and Accessibility}

It is early for drawing conclusions with regard to fairness and accessibility. In The Netherlands, current seaweed production takes place in a pilot- and experimental basis. Factors such as the Dutch maritime geography, research and innovation infrastructure, as well as the policy objectives of producing proteins locally might change this situation.

\section{Animal Health and Wellbeing}

In a review, van den Burg and colleagues argue that seaweed poorly contributes to the energy required by livestock "because of the high fibre content and low digestibility of the polysaccharides and the relative low fat content" — see also [91]. Recent research claims that the protein content variates between species but that many "have too little digestible proteins" [92]; see also [79]. These references would mainly apply for monogastric animals. For ruminant species Makkar et al. [93] write that there is a lot of variation between seaweeds, but that some have a nutritional value and digestibility comparable to good quality fodder (see Table 6).

However, contaminants such as heavy metals and minerals accumulate in seaweed and can become a risk for animals of all species [91,92] — see also the discussion on bromoform above. No matter how, some seaweed species are already used as feed ingredients for pets and livestock [80] (and references therein). The literature also claims that some of their components might have antibacterial effects on livestock, which might reduce the need of antibiotics [31,92] — see also Bikker et al. [79] for positive effects of amino acid pattern in feed. 
Table 6. Nutrient content of some seaweed species harvested along the coastal regions of North-western Europe as analysed in Bikker et al. [79] (See [79] for references, acronyms, values and calculations. Notes: a. Calculated as 1000-ash; b. Calculated as nitrogen $\times 500$; c. Calculated as 1000-ash-CP-Cfat-starch-sugars; $\mathrm{d}$, e and f. Detected ADL content was 0, which is under the limit for accurate detection of ADL).

\begin{tabular}{|c|c|c|c|c|c|c|c|c|c|c|c|c|c|c|}
\hline & & $\mathrm{g} / \mathrm{kg}$ & g/kg DM & & & & & & & & & & & \\
\hline $\begin{array}{c}\text { Seaweed } \\
\text { Classification }\end{array}$ & Species & DM & Ash & $\mathrm{OM}^{\mathrm{a}}$ & $C P^{b}$ & Cfat & Cfibre & Sugar & Starch & NSP $^{c}$ & NDF & ADF & ADL & HCI-ash \\
\hline \multirow[t]{5}{*}{ Brown } & I. digitata (S) & 891 & 275 & 725 & 92 & 16 & 73 & 2 & 2 & 618 & 120 & 200 & 36 & 7 \\
\hline & I. digitata (I) & 923 & 367 & 633 & 82 & 11 & 69 & 1 & 1 & 545 & 91 & 164 & 28 & 7 \\
\hline & S. latissima (S) & 874 & 243 & 757 & 74 & 10 & 71 & 6 & 1 & 668 & 122 & 185 & 23 & 11 \\
\hline & S. latissima $(\mathrm{F})$ & 902 & 273 & 727 & 117 & 12 & 62 & 1 & 1 & 603 & 96 & 171 & 7 & 6 \\
\hline & A. nodosum (I) & 910 & 411 & 589 & 57 & 10 & 88 & 1 & 1 & 530 & 152 & 298 & 48 & 11 \\
\hline \multirow[t]{4}{*}{ Red } & P. palmata (S) & 939 & 209 & 791 & 141 & 12 & 35 & 35 & 17 & 594 & 312 & 50 & 6 & 7 \\
\hline & P.palmata $(\mathrm{F})$ & 949 & 228 & 772 & 134 & 13 & 28 & 48 & 22 & 555 & 347 & 42 & 5 & 4 \\
\hline & G. crispus (S) & 883 & 176 & 824 & 98 & 17 & 31 & 6 & 26 & 691 & 392 & 40 & 9 & 2 \\
\hline & G. crispus (I) & 899 & 445 & 555 & 125 & 7 & 45 & 3 & 90 & 351 & 190 & 53 & 14 & 152 \\
\hline \multirow[t]{5}{*}{ Green } & U. lactuca (S) & 842 & 243 & 757 & 70 & 23 & 76 & 24 & 75 & 567 & 385 & 141 & 70 & 20 \\
\hline & U. lactuca (I) & 883 & 173 & 827 & 248 & 21 & 57 & 7 & 42 & 530 & 259 & 135 & 69 & 11 \\
\hline & Soybean meal ${ }^{\mathrm{d}}$ & 900 & 73 & 927 & 531 & 28 & ND & 134 & 10 & 224 & 90.6 & 51.4 & $\mathrm{UD}^{\mathrm{f}}$ & ND \\
\hline & Sugar beet pulp $\mathrm{e}$ & 917 & 79 & 921 & 88 & 14 & ND & 234 & 4 & 581 & 356 & 182 & 8 & ND \\
\hline & Alfalfa $\mathrm{e}$ & 927 & 125 & 875 & 174 & 27 & ND & 54 & 19 & 601 & 419 & 318 & 77 & ND \\
\hline
\end{tabular}

Cfat $=$ crude fat, Cfibre $=$ crude fibre, $\mathrm{S}=$ harvested in Scotland, $\mathrm{F}=$ harvested in France, $\mathrm{I}=$ harvested in Ireland, $\mathrm{UD}=$ under detection limit, $\mathrm{ND}=$ not determined. Each value in the table is based on one analysis in duplicated. 


\subsection{Localized Production and Alternative Plant-Based Feed Sources}

The literature claims that biomass from marginal lands (i.e., less or unsuitable land for crop production due to rainfall, swampy conditions, or poor terrain limitations) grazed by ruminants might relieve pressure on arable land and on food-feed competition [73]. In The Netherlands, two thirds of the land area is used for agriculture and horticulture, of which $53 \%$ is grassland (mainly used by the dairy sector), and $12 \%$ is used to produce feed-crops, mainly maize [69]. As aforementioned, there are other biomass (grains, scraps, etc.) and agriculture (by-)products that are being used as feed. However, the great majority of the raw materials for compound feed is being imported or could not be identified as a new feed source $[69,94]$. This category thus concerns the production of plants in The Netherlands that have not been traditionally used as feed source, or the local production of others that have been and are used for feeding livestock, but that have been traditionally imported. They are usually labelled as circular feed. Among the former we find, for instance, sorghum (a genus from within the grass family Poaceae), lupine (Lupinus), poppy seed (Papaver somniferum), invasive aquatic plants as duckweeds (Lemna L.), etc. Among the latter we find, for example, the local production of soya beans. Within this category, the use as feed of biomass/residual flows produced from the management of ditches, creeks and streams, and roadsides is also considered.

\subsubsection{Soya Beans}

The EU's soya self-sufficiency level is estimated at 5\% [95]. The area in the EU cultivated with soya reached almost 1 million ha in 2018 with a production of 2.8 million tonnes [95], the major producing countries being Italy, France, and Romania.

The Dutch dairy industry aims to produce $65 \%$ of the proteins consumed by dairy cows within the farm itself or within a radius of $20 \mathrm{~km}$ in 2025 (https:/ / www.nzo.nl/media/ uploads /2018/07/NZO-Rapport-Klimaatverantwoorde-zuivelsector-in-Nederland-december2018.pdf (accessed on 1 September 2021)). The dairy sector expects that this might increase the production of crops rich in proteins and of the biodiversity in pastures.

In 2017, 14 EU countries signed the 'European Soya Declaration' to promote the local (EU) production of soya; since then, some more countries signed the declaration (https: / / www.donausoja.org/en/about-us/the-association/europe-soya-declaration/ (accessed on 1 September 2021)). The Netherlands has to cultivate 10,000 hectares to meet the government's target under the Green Deal policy of 2016. If this land would produce 40,000 tons of soya, this could replace $1-1.5 \%$ of soya meal used in animal feed in The Netherlands. Nevertheless, in The Netherlands only 132 hectares were used to produce soya in 2020, which is 73\% less than the 476 ha cultivated in 2019 (www.cbs.nl/en-gb / news / 2020 / 40 /less-protein-crop-farming-in-the-netherlands (accessed on 1 November 2021)). In 2018, soya production reached 541 ha. Experts say that this is because of a combination of factors such as varieties that are not adapted to climate conditions, which delivers low production performance with a non-constant protein content, and all this combined with a low human consumption of soya products (www.boerderij.nl/nu-geen-perspectief-voor-nedersoja (accessed on 1 November 2021)). No matter how, experiments under the circularity flag are being conducted to locally produce soya (www.agroproeftuindepeel.nl/verhalen/ nedersoja-en-voedererwten-alternatief-sojaimport (accessed on 1 November 2021)).

\subsubsection{Sorghum and Lupine}

Sorghum, a crop of African origin, has attracted attention as an alternative/circular source of proteins for feed. Sorghum is claimed to grow roots that go deeper into the soil. Because of this, it might perform better in sandy and compacted soils and produce more dry matter with less water $[96,97]$. This is the type of soil mainly found in the Eastern and Southern Dutch provinces in which intensive livestock production takes place and where, because of the use of heavy machines, soil problems of compaction and subsequent water management and drought occur [98,99]. Climate change has heightened drought problems. The Dutch cultivation and silage of sorghum is still experimental. Russia 
(90,000 estimated ha) and France (70,000 estimated ha) are the largest producers in Europe (Productivity. Sorghum the reliable crop.-Sorghum ID (sorghum-id.com) (accessed on 1 November 2021)).

Lupine is also being promoted as a circular feed source as it is claimed that it binds nitrogen, improves soil quality, and is drought resistant and rich in proteins, and agronomic experimentation is being conducted. However, the area cultivated with sweet lupins has been enlarged from 58 ha in 2019 to up to 100 ha in 2020 (Table 7).

Table 7. Yearly cultivation area of protein-rich arable crops in The Netherlands. (* Provisional figures)-Source CBS (Less protein crop farming in The Netherlands (cbs.nl) (https: / /www.cbs.nl/ en-gb/news/2020/40/less-protein-crop-farming-in-the-netherlands (accessed on 1 October 2021)).

\begin{tabular}{cccccc}
\hline & Alfalfa (ha) & Field Beans (ha) & Field Peas (ha) & Soya (ha) & \multicolumn{2}{c}{ Sweet Lupins (ha) } \\
\hline 2010 & 6422.43 & 346.47 & 493.19 & 0.05 & 48.49 \\
\hline 2011 & 6388.48 & 305.78 & 157.44 & 6.66 & 30.13 \\
\hline 2012 & 5908.43 & 331.54 & 141.33 & 11.18 & 63.44 \\
\hline 2013 & 5484.63 & 228.29 & 230.97 & 33.30 & 66.92 \\
\hline 2014 & 5256.53 & 279.58 & 189.41 & 110.15 & 101.60 \\
\hline 2015 & 7782.07 & 360.43 & 272.94 & 193.54 & 78.20 \\
\hline 2016 & 8356.15 & 427.08 & 201.00 & 140.29 & 35.18 \\
\hline 2017 & 7494.67 & 572.94 & 263.06 & 446.87 & 50.87 \\
\hline 2018 & 7559.31 & 704.90 & 257.24 & 540.84 & 56.05 \\
\hline 2019 & 7619.53 & 949.34 & 312.74 & 475.62 & 57.58 \\
\hline $2020 *$ & 7510.73 & 1091.78 & 276.99 & 132.38 & 100.22 \\
\hline
\end{tabular}

4.3.3. Ditches, Creeks and Streams, and Roadside Management Produced Biomass/Residual Flows

Circularity thinking is also expanding the areas in which we search for biomass. Vijn et al. [69] estimated that the amount of roadside clippings was around 240,000 to 250,000 tons of DM-i.e., between 800,000 and 1,200,000 tons of fresh biomass. However, residual flows of roadside management could be polluted. Regarding creeks and streams there is a logistical problem as many ditches are not accessible by road, which is why this biomass is usually left behind.

\subsubsection{Evaluation}

Safeguard the Health of Ecosystems

The effects of new locally produced protein crops on local ecosystems will most probably depend on the total areal required and on the production method, for instance, as high input (synthetic fertilizers and pesticides) monoculture crops or as more organic approaches. So far, half of the 100 lupine ha is cultivated organically.

Some of these crops are not yet adapted to local conditions though. Sorghum has attracted attention because of its depth rooting capacity and subsequent capacity to stand drought and restore the soil. Recent research has compared (between 2017 and 2020) maize with sorghum varieties that have been specially developed for Dutch agriculture. Maize and sorghum performed similarly in terms of root depth, dry matter, and nitrate leaching [100]. The advice is to further organize plant breeding programs to develop sorghum varieties that are tolerant to low temperatures early in the season and which can perform in both wet as well as dry conditions [100]. Similar conclusions can be made regarding soya (see here above). So, although promising, a breeding process has to be organized to adapt these crops to local ecosystems, maintaining their positive traits.

Finally, there are many experiments and initiatives exploring the possibility to use the biomass produced from the management of nature-protected areas, roadsides, and creeks and streams to restore agricultural soils by increasing organic matter. A history of 
monoculture intensive agricultural production that has leaned on synthetic fertilizers and heavy machines has negatively affected the soils [99]. The application of green fertilizers rich in organic matter might have positive effects on agricultural ecosystems [101]. An important question here, therefore, is whether this biomass is better used for feed or as a source of organic matter for agricultural soils.

Avoid the Production of Unnecessary Products and Use/Recycle Biomass Effectively (Food vs. Feed)

The nutritional feed value of soya is well documented [102]. However, the local production of soya beans is not getting traction. In 2020 the Dutch soya areal decreased $73 \%$ with respect to 2019 . To meet the feed needs of the current Dutch herd, a substantial number of hectares is required. For example, with a high yield of 4 tons per hectare, The Netherlands will need approx. 550,000 hectares, i.e., 13\% of its land. Moreover, with this high production rate you might get around 1.8 tons of protein per hectare, while gras silage yields around 1.98 and maize 1.2-1.44 tons of protein per hectare. Here, we are once again confronted with the food-feed dilemma. On the one hand, protein-rich crops are being promoted because of the role that they can play in the circular transition, in the sense of localized production of proteins for feed concentrates with the final objective of feeding people with animal products. On the other hand, to meet the food transition aimed at, among others, introducing more plant-based proteins in diets, this areal and crops could be used directly for food.

Furthermore, humans (and other monogastric animals) are unable to digest the biomass produced from Dutch roadsides and creeks and streams. Its usage as feed for ruminants could increase the local production of proteins. The quality of the roadside clipping would likely be suitable only for young stock raising for animals between 1 and 2 years old. This would replace low quality forage at the farms and would likely not contribute substantially to replacing imported protein sources. The estimated capacity of 240,000 to 250,000 tons of DM production of roadside clippings [69] could feed approx. 70,000-100,000 (between 1-2 year old) dairy cows. But dairy farmers would have then a lot of low quality grass silage left which usually is used to feed these cows. Putting this into perspective, in The Netherlands there are more than 1.5 million dairy cows, with an additional (approx.) 400,000 1-2 year old cows.

Fairness and Accessibility

Taking advantage of biomass produced from the management of roadsides and creeks and streams is currently a relatively cheap type of feed source as the managers of these areas have to get rid of this biomass. However, biomass is becoming more expensive as our awareness of its value evolves. The costs of accessing it will probably increase in the near future (e.g., competition with soil restoration). Moreover, the production areas are extended (not concentrated in a place) and sometimes of difficult access, because of which recollection and transport might become an issue.

Local production of protein rich crops might help maintaining the labour force employed in the agricultural/livestock sectors in The Netherlands. Moreover, if production gets localized and specialized to feed high-value livestock to meet the national or European (depending on the definition of scale for biogeochemical cycles) demands, it might improve the labour wages and skills in the agricultural sector. What localizing the production of soya will mean for, e.g., soya Brazilian farmers and other workers and stakeholders within the chain is difficult to envision.

Finally, although The Netherlands is one of the richest countries in Europe, it is estimated that according to Dutch standards (Statistics Netherlands and Social and Cultural Planning Office), around 1 million people live under the low-income threshold, in poverty. Right now, because the linear and industrialized form of livestock production (based on relative cheap import of proteins), these people have, to a certain extent, access to high 
quality and cheap meat, milk, etc. The question here is whether this will remain this way if localized production will get traction.

Animal Health and Wellbeing

In general, the nutritional values of locally produced soya, lupin, or sorghum are okay to feed livestock. Different varieties might differ in the chemical composition, crude protein, ether extract, trypsin inhibitor activity, etc. [102]. Research has shown that soya cultivated in Europe might get contaminated with "fungi, yeast and mycotoxins, mainly zearalenone and deoxynivalenol" [102]. This might be due to the weather conditions during the harvest period, which might influence the digestibility of feed and indicate a possible requirement of manufacture [102]. Moreover, a strict check/cleaning process is required before biomass produced from (nearby) roadsides management is fed to livestock as this is usually contaminated with bulky waste and heavy metals produced in the combustion of fossil fuel by vehicles [103].

\section{Reflection and the Circular Way Forward}

The concept of circularity is gaining terrain among policy makers, industry, nongovernmental organizations, and researchers to address key sustainability problems. The Dutch government currently encourages a circularity transition in the livestock and agricultural domains. Metaphorically speaking, people use the expression 'squaring the circle' to indicate something impossible. We have also used this expression here (see title and Section 3). However, we do not mean to say that it is impossible to convert linear agricultural and livestock production systems into circular ones. Rather, we have evaluated some emerging circular feed categories through a square-like framework/cadre formed by four evaluation criteria.

The framework is specifically designed for the evaluation of feed categories and initiatives. The four criteria of this framework form a coherent whole in which the different elements avoid argument duplications. The first two criteria concern standard circularity principles aimed at both stopping and preventing environmental damage as well as a focus on natural resources efficiency usage: (I) safeguard the health of ecosystems and (II) avoid the production of unnecessary products and use/recycle biomass effectively, regarding also possible food-feed competition. In addition, two 'people' and 'animal' centred principles have been integrated: (III) fairness and accessibility and (IV) animal (and human) health and wellbeing. This approach fits an emerging interest to not only look at biogeochemical cycles but also at animal and human wellbeing aspects for assessing and studying circular (feed) options and practices [51,65].

The three evaluated categories are: (1) food waste; (2) seaweed/macroalgae; and (3) localized production and alternative plant-based feed sources. As it has been argued, (1) although avoiding or reducing food waste ought to be the priority, valuing unavoidable food waste as a feed source seems to be a circular solution [1,33]. It brings back into the food system unused products that are at the end of the food chain and it reduces the land use of livestock production [1]. In The Netherlands, assuming (unrealistically) total collection, approximately $1.5 \%$ of compound feed produced could be replaced by food waste. Besides, a change in the regulatory framework is still required and afterwards, separation or/and processing steps will be essential to avoid public health issues [33,74].

(2) Seaweed could expand the number of feed sources and amount of available raw material $[77,79,80,93]$. If cultivated offshore, it can reduce the pressure on forest and land ecosystems (land use and land use change) of feed production. One wonders, however, how circular/linear growing offshore seaweed is compared to land-based plant production as both produce raw materials either from land or sea and need to manage nutrients and other inputs in the production process. The $\mathrm{CO}_{2}$ footprint of growing seaweed as currently reported is higher than key land based raw materials [87]. Lastly, current production volumes in Europe, and the required upscaling and optimalization of production processes that still have to take place, suggest that it may take a while before seaweed substantially 
and sustainably can replace, e.g., imported feed ingredients. In The Netherlands there are a few companies that produce seaweed. Production volumes of offshore cultivation is in a pilot stage and therefore are difficult to obtain. Production is limited to S. latissima and concentrated in approx. 10-15 hectares (Nauta, personal communication January 2022).

(3) Regarding "localized production and production of alternative plant-based feed sources", current production of alternatives for imported feed in The Netherlands is very low. Under current conditions, the acreage used for this type of production will only increase if the chosen crops display better cost-effectiveness and environmental performance than optimized crop varieties that are currently cultivated in the country. Finally, the largest amount of new material potentially entering the feed stream is biomass from ditches, creeks and streams, and roadside management.

In philosophy, an argument is circular if the premise is logically equivalent to the conclusion, i.e., the same truth arguments and claims are employed-circular reasoning 'circulus in probando'. When addressing the circular transition regarding feed components we find developments concerning categories such as algae, insects, locally produced soya, or waste from abattoirs or the kitchen. The framing sounds something like that these are circular feed sources and that, therefore, since we are busy with these categories we are engaged in a circular transition. In this sense, however, and if we look to the Dutch internationally oriented feed and livestock sectors and economy (Section 2) and to the production volumes of some of the circular feeds here addressed (Section 4), one wonders whether it is possible to speak about an ongoing (circularity) transition within the feed domain. For instance, the local production of soya is irrelevant compared to the utilized in feed. Moreover, seaweed production is still, and logically, approached from an experimental type of approach. No matter how, algae production or the local cultivation of protein rich crops (e.g., alfalfa), or the production of insects on waste streams, still have the potency to strengthen the circular feed transition in the near future [44].

Besides, a focus on resources efficiency and the efforts conducted to reduce dependency on imported unsustainable sources might have accelerated the recent changes regarding the regulation concerning insects, livestock leftovers produced at farms and abattoirs, and food waste. These are qualitatively and quantitively interesting categories [33,73,104,105]. If properly organized, they could reintegrate into the system a good amount of high-quality feed elements. Although, as aforementioned, one wonders whether these current 'waste' biomass streams will not be, in the near future, upgraded to high-quality food elements.

To conclude, in-depth evaluations of feed sources are required to gain a better understanding of their potency. The explicit focus on and the elaboration and operationalization of ecological principles within circularity indicates a move in the right sustainability direction regarding biomass use-e.g., as feed. The explicit connection and articulation of human- and animal-centred principles and practices might strengthen and facilitate further circularity within the sustainability transition.

Author Contributions: D.P.-R. and H.v.L. contributed to the study conception and design. Material preparation, data collection, and analysis were performed by M.V., D.P.-R., and H.v.L. The first draft of the manuscript was written by D.P.-R., and all authors commented on previous versions of the manuscript. All authors have read and agreed to the published version of the manuscript.

Funding: This research was funded under the Knowledge Base program 1-1-D-1 “Governance in transition", Wageningen University \& Research Centre.

Data Availability Statement: Data sharing is not applicable to this article.

Acknowledgments: Our thanks to Izak Vermeij for kindly sharing information regarding slaughter remains produced in abattoirs and cadavers of farm animals in The Netherlands; R.W. (Reinier) Nauta and Wouter Muizelaar for information on seaweeds; and A.P. (Bram) Bos for the comments made on previous drafts of this article. They all work at Wageningen Livestock Research except R.W. Nauta, who works at Wageningen Marine Research.

Conflicts of Interest: The authors declare that they are not aware of possible competing interests. 


\section{References}

1. Van Zanten, H.H.E.; Herrero, O.; van Hal, E.; Röös, A.; Muller, T.; Grarnett, P.J.; Gerber, C.; Shcader, C.; de Boer, I.J.M. Defining a Land Boundary for Sustainable Livestock Consumption. Glob. Change Biol. 2018, 24, 4185-4194. [CrossRef] [PubMed]

2. Van Hal, O. Upcycling Biomass in a Circular Food System-The Role of Livestock and Fish. Ph.D. Thesis, Wageningen University \& Research, Wageningen, The Netherlands, 2020.

3. OECD/FAO. OECD-FAO Agricultural Outlook 2020-2029; OECD: Paris, France, 2020.

4. Mottet, A.; de Haan, C.; Falcucci, A.; Tempio, G.; Gerber, P. Livestock: On Our Plates or Eating at Our Table? A New Analysis of the Feed/Food Debate. Glob. Food Secur. 2017, 14, 1-8. [CrossRef]

5. Gerber, J.P.; Steinfeld, H.; Henderson, B.; Mottet, A.; Opio, C.; Dijkman, J.; Falcucci, A.; Tempio, G. Tackling Climate Change through Livestock-A Global Assessment of Emissions and Mitigation Opportunities; Food and Agriculture Organization of the United Nations (FAO): Rome, Italy, 2013.

6. Reisinger, A.; Clark, H. How Much Do Direct Livestock Emissions Actually Contribute to Global Warming? Glob. Change Biol. 2017, 24, 1749-1761. [CrossRef]

7. Schoumans, O.; Ehlert, P.; Hanegraaf, M.; Römkens, P.; Pustjens, A.; de Koeijer, T.; de Boer, H.; Nienhuis, C.; Kortstee, H.; Smit, A.; et al. Development of a Conceptual Framework to Evaluate Organic Fertilisers: Assessment on Soil Quality and Agronomic, Environmental and Economics Aspects; Wageningen Economic Research: Wageningen, The Netherlands, 2019.

8. Bouwman, A.F.; Beusen, A.; Lassaletta, L.; Van Apeldoorn, D.F.; Van Grinsven, H.J.M.; Zhang, J.; van Ittersum, M. Lessons from Temporal and Spatial Patterns in Global Use of N and P Fertilizer on Cropland. Sci. Rep. 2017, 7, 40366. [CrossRef]

9. Leip, A.; Billen, G.; Garnier, J.; Grizzetti, B.; Lassaletta, L.; Reis, S.; Simpson, D.; Sutton, M.A.; de Vries, W.; Weiss, F.; et al. Impacts of European Livestock Production: Nitrogen, Sulphur, Phosphorus and Greenhouse Gas Emissions, Land-Use, Water Eutrophication and Biodiversity. Environ. Res. Lett. 2015, 10, 115004. [CrossRef]

10. European Commission. Closing the Loop-An Eu Action Plan for the Circular Economy-Com(2015) 614 Final; European Commission: Brussels, Belgium, 2015.

11. European Commission. Measuring Progress Towards Circular Economy in the European Union-Key Indicators for a Monitoring Framework - Com(2018) 29 Final; European Commission: Brussels, Belgium, 2018.

12. Åkerman, M.; Humalisto, N.; Pitzen, S. Material Politics in the Circular Economy: The Complicated Journey from Manure Surplus to Resource. Geoforum 2020, 116, 73-80. [CrossRef]

13. LNV. Agriculture, Nature and Food: Valuableand Connected. The Netherlands as a Leader in Circular Agriculture; Ministry of Agriculture, Nature and Food Quality of The Netherlands (LNV): The Hague, The Netherlands, 2018.

14. LNV. Plan of Action New Perspective for Agriculture, Nature and Food Quality; Ministry of Agriculture, Nature and Food Quality of The Netherlands: The Hague, The Netherlands, 2019.

15. Jukema, D.G.; Ramaekers, P.; Berkhout, P. De Nederlandse Agrarische Sector in Internationaal Verband-Editie 2021; Wageningen Economic Research \& Centraal Bureau voor de Statistiek: Wageningen, The Netherlands, 2021.

16. Nevedi. Grondstoffenwijzer; Diervoeders Voor Een Circulaire Voedselproductie; 3rd ed.; Nederlandse Vereniging Diervoederindustrie (Nevedi): Rijswijk, The Netherlands, 2019.

17. TLN. Resultaten Ketenonderzoek Diervoeder; Transport en Logistiek Nederland (TLN): Zoetermeer, The Netherlands, 2019.

18. SecureFeed. SecureFeed Jaarverslag 2019; SecureFeed: Wageningen, The Netherlands, 2019.

19. OPNV. Minder Afzet Vochtrijke Diervoeders in 2019. Afzet Van Vochtrijke Voedermiddelen in 2019; Overleggroep Producten Natte Veevoeders (OPNV): Venray, The Netherlands, 2019.

20. Comité Het. Dutch Trade in Grains, Seeds and Pulses; Royal Dutch Grain and Feed Trade Association Het Comité: Zoetermeer, The Netherlands, 2019.

21. FEFAC. Feed E Food 2020; European Feed Manufacturers' Federation (FEFAC): Brussel, Belgium, 2021.

22. Taelman, S.E.; De Meester, W.; van Dijk, W.; da Silva, V. Environmental Sustainability Analysis of a Protein-Rich Livestock Feed Ingredient in The Netherlands: Microalgae Production Versus Soybean Import. Resour. Conserv. Recycl. $2015,101,61-72$. [CrossRef]

23. Post, P.M.; Hogerwerf, L.; Bokkers, E.A.; Baumann, B.; Fischer, P.; Rutledge-Jonker, S.; Hilderink, H.; Hollander, A.; Hoogsteen, M.J.; Liebman, A.; et al. Effects of Dutch Livestock Production on Human Health and the Environment. Sci. Total Environ. 2020, 737, 139702. [CrossRef]

24. Bos, J.F.; Smit, A.B.L.; Schröder, J.J. Is Agricultural Intensification in The Netherlands Running up to Its Limits. NJAS-Wagening. J. Life Sci. 2013, 66, 65-73. [CrossRef]

25. Leenstra, F.; Vellinga, T.; Neijenhuis, F.; de Buiseonjé, F.; Gollenbeek, L. Manure: A Valuable Resource; Wageningen Livestock Research: Wageningen, The Netherlands, 2019.

26. Pexas, G.; Mackenzie, S.G.; Wallace, M.; Kyriazakis, I. Environmental Impacts of Housing Conditions and Manure Management in European Pig Production Systems through a Life Cycle Perspective: A Case Study in Denmark. J. Clean. Prod. 2020, $253,120005$. [CrossRef]

27. Pacheco, P.; Mo, K.; Dudley, N.; Shapiro, A.; Aguilar-Amuchastegui, N.; Ling, P.Y.; Anderson, C.; Marx, A. Deforestation Fronts: Drivers and Responses in a Changing World; World Wide Fund for Nature Gland: Gland, Switzerland, 2021.

28. Hoste, R.; Judge, L. Impact Assessment of the Dutch Transition Towards Certified Soy; Wageningen Economic Research: Wageningen, The Netherlands, 2018. 
29. De Maria, M.; Robinson, E.J.Z.; Kangile, J.R.; Kadigi, R.; Dreoni, I.; Couto, M.; Howai, N.; Peci, J.; Fiennes, S. Global Soybean Trade. The Geopolitics of a Bean. UK Research and Innovation Global Challenges Research Fund (UKRI GCRF) Trade. Dev. Environ. Hub 2020. [CrossRef]

30. Schilling-Vacaflor, A.; Lenschow, A.; Challies, E.; Cotta, B.; Newig, J. Contextualizing Certification and Auditing: Soy Certification and Access of Local Communities to Land and Water in Brazil. World Dev. 2021, 140, 105281. [CrossRef]

31. De Boer, I.J.M.; van Ittersum, M.K. Circularity in Agricultural Production; Wageningen University \& Research: Wageningen, The Netherlands, 2018.

32. van der Meer, R.W. Watergebruik in De Land- En Tuinbouw, 2015 En 2016; Wageningen Economic Research: Wageningen, The Netherlands, 2018.

33. zu Ermgassen, E.K.; Phalan, B.; Green, R.E.; Balmford, A. Reducing the Land Use of Eu Pork Production: Where There's Swill, There'sa Way. Food Policy 2016, 58, 35-48. [CrossRef]

34. Virah-Sawmy, M.; Durán, A.P.; Green, J.M.; Guerrero, A.M.; Biggs, D.; West, C.D. Sustainability Gridlock in a Global Agricultural Commodity Chain: Reframing the Soy-Meat Food System. Sustain. Prod. Consum. 2019, 18, 210-223. [CrossRef]

35. Hall, D.; Ames, R.T. Anticipating China: Thinking through the Narratives of Chinese and Western Culture; State University of New York Press: New York, NY, USA, 1995.

36. Fidelis, M.; De Moura, C.; Junior, T.K.; Pap, N.; Mattila, P.H.; Mäkinen, S.; Putnik, P.; Kovačević, D.B.; Tian, Y.; Yang, B.; et al. Fruit Seeds as Sources of Bioactive Compounds: Sustainable Production of High Value-Added Ingredients from by-Products within Circular Economy. Molecules 2019, 24, 3854. [CrossRef]

37. Sachs, J.D.; Schmidt-Traub, G.; Mazzucato, M.; Messner, D.; Nakicenovic, N.; Rockström, J. Six Transformations to Achieve the Sustainable Development Goals. Nat. Sustain. 2019, 2, 805-814. [CrossRef]

38. Moraga, G.; Huysveld, S.; Mathieux, F.; Blengini, G.A.; Alaerts, L.; Van Acker, K.; de Meester, S.; Dewulf, J. Circular Economy Indicators: What Do They Measure? Resour. Conserv. Recycl. 2019, 146, 452-461. [CrossRef]

39. Calisto Friant, M.C.; Vermeulen, W.J.; Salomone, R. A Typology of Circular Economy Discourses: Navigating the Diverse Visions of a Contested Paradigm. Resour. Conserv. Recycl. 2020, 61, 104917. [CrossRef]

40. Ellen MacArthur Foundation. Towards a Circular Economy: Business Rationale for an Accelerated Transition; Ellen MacArthur Foundation: Chicago, IL, USA, 2015.

41. Termeer, C.J.; Dewulf, A. A Small Wins Framework to Overcome the Evaluation Paradox of Governing Wicked Problems. Policy Soc. 2019, 38, 298-314. [CrossRef]

42. De Haas, W.; van Hoof, L.; De Koning, S.; de Lauwere, C.; Pleitje, M.; Puente-Rodríguez, D. Experimenteren Om Te Leren; Governance in De Transitie Naar Kringlooplandbouw; Wageningen Environmental Research: Wageningen, The Netherlands, 2021.

43. Dagevos, H.; Lauwere, C. Circular Business Models and Circular Agriculture: Perceptions and Practices of Dutch Farmers. Sustainability 2013, 3, 1282. [CrossRef]

44. Muscat, A.; de Olde, E.M.; Ripoll-Bosch, R.; Van Zanten, H.H.E.; Metze, T.A.P.; Termeer, C.J.; Van Ittersum, M.K.; de Boer, H.C. Principles, Drivers and Opportunities of a Circular Bioeconomy. Nat. Food 2021, 2, 561-566. [CrossRef]

45. De Zwarte, I.; Candel, J. Tien Miljard Monden: Hoe We De Wereld Gaan Voeden in 2050; Prometheus: Amherst, NY, USA, 2020.

46. Dawson, C.; Hilton, J. Fertiliser availability in a resource-limited world: Production and recycling of nitrogen and phosphorus. Food Policy 2011, 36, S14-S22. [CrossRef]

47. Geissler, B.; Hermann, L.; Mew, M.C.; Steiner, G. Striving toward a Circular Economy for Phosphorus: The Role of Phosphate Rock Mining. Minerals 2018, 8, 395. [CrossRef]

48. Trimmer, J.T.; Guest, J.S. Recirculation of Human-Derived Nutrients from Cities to Agriculture across Six Continents. Nat. Sustain. 2018, 1, 427-435. [CrossRef]

49. Van Middelkoop, J.C.; Holshof, G. Nitrogen Fertilizer Replacement Value of Concentrated Liquid Fraction of Separated Pig Slurry Applied to Grassland. Commun. Soil Sci. Plant Anal. 2017, 48, 1132-1144. [CrossRef]

50. van der Linden, A.; de Olde, E.M.; Mostert, P.F.; de Boer, I.J.M. A Review of European Models to Assess the Sustainability Performance of Livestock Production Systems. Agric. Syst. 2020, 182, 102842. [CrossRef]

51. Corona, B.; Shen, L.; Reike, D.; Carreón, J.R.; Worrell, E. Towards Sustainable Development through the Circular Economy-A Review and Critical Assessment on Current Circularity Metrics. Resour. Conserv. Recycl. 2019, 151, 104498. [CrossRef]

52. Holt-Giménez, E.; Shattuck, A.; Altieri, M.; Herren, H.; Gliessman, S. We Already Grow Enough Food for 10 Billion People and Still Can't End Hunger. J. Sustain. Agric. 2012, 36, 595-598. [CrossRef]

53. Singh, R.B.; Watson, R.R.; Takahashi, T. The Role of Functional Food Security in Global Health; Elsevier Academic Press: Amsterdam, The Netherlands, 2019.

54. Gordillo, G.; Jerónimo, O.M. Food Security and Sovereignty: Base Document for Discussion; Food and Agriculture Organization of the United Nations: Rome, Italy, 2013.

55. Kallis, G.; Kostakis, V.; Lange, S.; Muraca, B.; Paulson, S.; Schmelzer, M. Research on Degrowth. Annu. Rev. Environ. Resour. 2018, 43, 291-316. [CrossRef]

56. Ghisellini, P.; Cialani, C.; Ulgiati, S. A Review on Circular Economy: The Expected Transition to a Balanced Interplay of Environmental and Economic Systems. J. Clean. Prod. 2016, 114, 11-32. [CrossRef]

57. Diana, A.; Lorenzi, V.; Penasa, M.; Magni, E.; Alborali, G.L.; Bertocchi, L.; De Marchi, M. Effect of welfare standards and biosecurity practices on antimicrobial use in beef cattle. Sci. Rep. 2020, 10, 1-13. [CrossRef] 
58. Grandin, T. Improving Animal Welfare 2nd Edition: A Practical Approach; CABI: Oxfordshire, UK, 2015.

59. Llonch, P.; Mainau, E.; Ipharraguerre, I.R.; Bargo, F.; Tedó, G.; Blanch, M.; Manteca, X. Chicken or the Egg: The Reciprocal Association between Feeding Behavior and Animal Welfare and Their Impact on Productivity in Dairy. Front. Vet. Sci. 2018, 5, 305. [CrossRef]

60. Christensen, T.; Denver, S.; Sandøe, P. How Best to Improve Farm Animal Welfare? Four Main Approaches Viewed from an Economic Perspective. Anim. Welf. 2019, 28, 95-106. [CrossRef]

61. Villettaz, R.M.; Rushen, J.; De Passillé, A.M.; Vasseur, E.; Orsel, K.; Pellerin, D. Associations between on-Farm Animal Welfare Indicators and Productivity and Profitability on Canadian Dairies: I. On Freestall Farms. J. Dairy Sci. 2019, 102, $4341-4351$. [CrossRef]

62. Villettaz, R.M.; Rushen, J.; De Passillé, A.M.; Vasseur, E.; Haley, D.; Pellerin, D. Associations between on-Farm Cow Welfare Indicators and Productivity and Profitability on Canadian Dairies: II. On Tiestall Farms. J. Dairy Sci. 2019, 102, $4352-4363$. [CrossRef]

63. Lahr, J.; Moermond, C.; Montforts, M.; Derksen, A.; Bondt, N.; Puister-Jansen, L.; de Koeijer, T.; Hoekstra, P. Diergeneesmiddelen in Het Miliue: Een Synthese Van De Huidige Kennis; Stichting Toegepast Onderzoek Waterbeheer: Amersfoort, The Netherlands, 2019.

64. Puente-Rodríguez, D.; Bos, A.P.; Lahr, J.; Hoeksma, P. Antimicrobiële Resistentie En Residuen Van Diergeneesmiddelen (Antibiotica) in Een Circulaire Veehouderij; Tegengaan Van Verspreiding Via Mest En Milieu; Wageningen Livestock Research: Wageningen, The Netherlands, 2019.

65. Vernooij, G.A.; Veldkamp, T.; Bos-Brouwers, H.E.J.; Hetterscheid, S.; Hendriks, W.H. Suitability of Side Flows as Ingredients for Poultry Feed: Wildcard Connected Circularity-Agrologistics of Side Flows: The Missing Link for Circularity by Design; Wageningen Food \& Biobased Research: Wageningen, The Netherlands, 2021.

66. House, J. Insects as Food in The Netherlands: Production Networks and the Geographies of Edibility. Geoforum 2018, 94, 82-93. [CrossRef]

67. Letlhogonolo, S.; Hassan, Z.; Myuelo, T.G.; Mabelebele, M. Insects' Production, Consumption, Policy, and Sustainability: What Have We Learned from the Indigenous Knowledge Systems? Insects 2021, 12, 432.

68. Vermeij, I.; Bosma, A.I.J. Notitie Voor Helpdeskvraag Flowchart Dierlijke Bijproducten; Wageningen Livestock Research: Wageningen, The Netherlands, 2010.

69. Vijn, M.; Dawson, A.; de Wolf, P.; van der Voort, M.; Vermeij, I. Mogelijkheden Verhogen Productie Diervoeders in Nederland; Verkenning Van De Mogelijkheden Tot Het Verhogen Van De Productie Van Diervoeders Uit Reststromen in Nederland Op Basis Van Beschikbare Kennis En Data; Stichting Wageningen Research: Wageningen, The Netherlands, 2019.

70. Gustavsson, J.; Cederberg, C.; Sonesson, U.; van Otterdijk, R.; Meybeck, A. Global Food Losses and Food Waste—Extent, Causes and Prevention; Food and Agriculture Organization of The United Nations: Rome, Italy, 2011.

71. Fan, L.; Ellison, B.; Wilson, N.L. What Food Waste Solutions Do People Support? J. Clean. Prod. 2021, 330, 129907. [CrossRef]

72. Georganas, A.; Giamouri, E.; Pappas, A.C.; Papadomichelakis, G.; Galliou, F.; Manios, T.; Tsiplakou, E.; Fegeros, K.; Zervas, G. Bioactive Compounds in Food Waste: A Review on the Transformation of Food Waste to Animal Feed. Foods 2020, 9, 291. [CrossRef]

73. Van Zanten, H. Feed Sources for Livestock: Recycling Towards a Green Planet. Ph.D. Thesis, Wageningen University \& Research, Wageningen, The Netherlands, 2016.

74. Dame-Korevaar, A.; Boumans, I.J.; Antonis, A.F.; van Klink, E.; de Olde, E.M. Microbial Health Hazards of Recycling Food Waste as Animal Feed. Futur. Foods 2021, 4, 100062. [CrossRef]

75. Stokvis, L.; van Krimpen, M.; Kwakkel, R.; Bikker, P. Evaluation of the nutritional value of seaweed products for broiler chickens' nutrition. Anim. Feed Sci. Technol. 2021, 280, 115061. [CrossRef]

76. Buschmann, A.H.; Camus, C.; Infante, J.; Neori, A.; Israel, Á.; Hernández-González, M.C.; Pereda, S.V.; Gomez-Pinchetti, J.L.; Golberg, A.; Tadmor-Shalev, N.; et al. Seaweed production: Overview of the global state of exploitation, farming and emerging research activity. Eur. J. Phycol. 2017, 52, 391-406. [CrossRef]

77. FAO. The Global Status of Seaweed Production, Trade and Utilization. In FAO Globefish Research Programme; Food and Agriculture Organization of The United Nations: Rome, Italy, 2018.

78. van den Burg, S.; Dagevos, H.; Helmes, R. Sustainable Seaweed Value-Chains: Economics, Consumer Attitudes and Environmental Impacts; Wageningen Economic Research: Wageningen, The Netherlands, 2018.

79. Bikker, P.; Stokvis, L.; van Krimpen, M.; van Wikselaar, P.; Cone, J. Evaluation of Seaweeds from Marine Waters in Northwestern Europe for Application in Animal Nutrition. Anim. Feed Sci. Technol. 2020, 263, 114460. [CrossRef]

80. Araújo, R.; Calderón, F.V.; López, J.S.; Azevedo, I.C.; Bruhn, A.; Fluch, S.; Tasende, M.G.; Ghaderiardakani, F.; Ilmjärv, T.; Laurans, M.; et al. Current Status of the Algae Production Industry in Europe: An Emerging Sector of the Blue Bioeconomy. Front. Mar. Sci. 2021, 7, 1247. [CrossRef]

81. He, P.; Xu, S.; Zhang, H.; Wen, S.; Dai, Y.; Lin, S.; Yarish, C. Bioremediation Efficiency in the Removal of Dissolved Inorganic Nutrients by the Red Seaweed, Porphyra Yezoensis, Cultivated in the Open Sea. Water Res. 2008, 42, 1281-1289. [CrossRef]

82. Campbell, I.; Macleod, A.; Sahlmann, C.; Neves, L.; Funderud, J.; Øverland, M.; Hughes, A.D.; Stanley, M. The Environmental Risks Associated with the Development of Seaweed Farming in Europe-Prioritizing Key Knowledge Gaps. Front. Mar. Sci. 2019, 6, 107. [CrossRef] 
83. Kinley, R.D.; De Nys, R.; Vucko, M.J.; Machado, L.; Tomkins, N.W. The Red Macroalgae Asparagopsis Taxiformis Is a Potent Natural Antimethanogenic That Reduces Methane Production During In Vitro Fermentation with Rumen Fluid. Anim. Prod. Sci. 2016, 56, 282-289. [CrossRef]

84. Li, X.; Norman, H.C.; Kinley, R.D.; Laurence, M.; Wilmot, M.; Bender, H.; de Nys, R.; Tomkins, N. Asparagopsis Taxiformis Decreases Enteric Methane Production from Sheep. Anim. Prod. Sci. 2018, 58, 681-688. [CrossRef]

85. Muizelaar, W.; Groot, M.; van Duinkerken, G.; Peters, R.; Dijkstra, J. Safety and Transfer Study: Transfer of Bromoform Present in Asparagopsis taxiformis to Milk and Urine of Lactating Dairy Cows. Foods 2021, 10, 584. [CrossRef]

86. Koesling, M.; Kvadsheim, N.P.; Halfdanarson, J.; Emblemsvåg, J.; Rebours, C. Environmental Impacts of Protein-Production from Farmed Seaweed: Comparison of Possible Scenarios in Norway. J. Clean. Prod. 2021, 307, 127301. [CrossRef]

87. Slegers, P.M.; Helmes, R.J.K.; Draisma, M.; Broekema, R.; Vlottes, M.; van den Burg, S.W.K. Environmental Impact and Nutritional Value of Food Products Using the Seaweed Saccharina latissima. J. Clean. Prod. 2021, 319, 128689. [CrossRef]

88. Van Dijk, W.; de Boer, J.A..; de Haan, M.H.A.; Mostert, P; Oenema, J.; Verloop, J. Rekenregels Van De Kringloopwijzer 2020; Achtergronden Van Bex, Bea, Ben, Bep En Bec: Actualisatie Van De 2019-Versie; Wageningen Research: Wageningen, The Netherlands, 2020.

89. Rajapakse, N.; Kim, S.K. Chapter 2-Nutritional and Digestive Health Benefits of Seaweed. Adv. Food Nutr. Res. 2011, 64, 17-28. [PubMed]

90. Kim, K.S.; Pangestuti, R.; Rahmadi, P. Chapter 5-Sea Lettuces: Culinary Uses and Nutritional Value. Adv. Food Nutr. Res. 2011, 64, 57-70. [PubMed]

91. Van den Burg, S.; Stuiver, F.; Veenstra, P.; Bikker, A.; López Contreras, A.; Palstra, J.; Broeze, H.; Jansen, R.; Jak, A.; Gerritsen, P.; et al. A Triple P Review of the Feasibility of Sustainable Offshore Seaweed Production in the North Sea; Wageningen University \& Research: Wageningen, The Netherlands, 2012.

92. Øverland, M.; Mydland, L.T.; Skrede, A. Marine macroalgae as sources of protein and bioactive compounds in feed for monogastric animals. J. Sci. Food Agric. 2019, 99, 13-24. [CrossRef] [PubMed]

93. Makkar, H.P.S.; Tran, G.; Heuzé, V.; Giger-Reverdin, S.; Lessire, M.; Lebas, F.; Ankers, P. Seaweeds for livestock diets: A review. Anim. Feed Sci. Technol. 2016, 212,1-17. [CrossRef]

94. Vellinga, T.; van Laar, H.; Thomassen, M.; de Boer, H.C.; Berkhout, P.; Alking, H. Milieueffecten Van Diervoeders; Animal Sciences Group van Wageningen UR: Lelystad, The Netherlands, 2009.

95. European Commission. Report from the Commission to the Council and the European Parliament: On the Development of Plant Proteins in the European Union; European Commision: Brussels, Belgium, 2018.

96. Farré, I.; Faci, J.M. Comparative Response of Maize (Zea Mays L.) and Sorghum (Sorghum Bicolor L. Moench) to Deficit Irrigation in a Mediterranean Environment. Agric. Water Manag. 2006, 83, 135-143. [CrossRef]

97. Schittenhelm, S.; Schroetter, S. Comparison of Drought Tolerance of Maize, Sweet Sorghum and Sorghum-Sudangrass Hybrids. J. Agron. Crop Sci. 2013, 200, 46-53. [CrossRef]

98. Brus, D.J.; van den Akker, J.J.H. How serious a problem is subsoil compaction in The Netherlands? A survey based on probability sampling. Soil 2018, 4, 37-45. [CrossRef]

99. Keller, T.; Sandin, M.; Colombi, T.; Horn, R.; Or, D. Historical increase in agricultural machinery weights enhanced soil stress levels and adversely affected soil functioning. Soil Tillage Res. 2019, 194, 104293. [CrossRef]

100. van den Akker, J.J.H.; Deru, J.G.C.; Sleiderink, J.W.M.; van Agtmaal, M.; Noij, I.G.A.M.; Heinen, M. Effecten Van Sorghum En Mais Op Bodem En Gewas Op Een Verdichte Zandgrond; Wageningen Environmental Research: Wageningen, The Netherlands, 2021.

101. Prasad, M.N.V. Handbook of Ecological and Ecosystem Engineering; John Wiley \& Sons Ltd.: Hoboken, NJ, USA, 2021.

102. Zaworska-Zakrzewska, A.; Kasprowicz-Potocka, M.; Twaruzek, M.; Kosicki, R.; Grajewski, J.; Wiśniewska, Z.; Rutkowski, A. A Comparison of the Composition and Contamination of Soybean Cultivated in Europe and Limitation of Raw Soy Seed Content in Weaned Pigs' Diets. Animals 2020, 10, 1972. [CrossRef]

103. Altaf, R.; Altaf, S.; Hussain, M.; Shah, R.U.; Ullah, R.; Ullah, M.I.; Rauf, A.; Ansari, M.J.; Alharbi, S.A.; Alfarraj, S.; et al. Heavy Metal Accumulation by Roadside Vegetation and Implications for Pollution Control. PLoS ONE 2021, 16, e0249147. [CrossRef] [PubMed]

104. Messina, C.M.; Gaglio, R.; Morghese, M.; Tolone, M.; Arena, R.; Moschetti, G.; Santulli, A.; Francesca, N.; Settanni, L. Microbiological Profile and Bioactive Properties of Insect Powders Used in Food and Feed Formulations. Foods 2019, 8, 400. [CrossRef] [PubMed]

105. Van Huis, A. Prospects of Insects as Food and Feed. Org. Agric. 2021, 11, 301-308. [CrossRef] 